\title{
Contribution to the study of genus Boletus, section Appendiculati: Boletus roseogriseus sp. nov. and neotypification of Boletus fuscoroseus Smotl.
}

\author{
JOSEF ŠUTARA $^{1 *}$, VÁClaV JANDA ${ }^{2}$, MARTIN KŘí̌ $^{3}$, Michal GRACA $^{4}$, MiROSLAV KOLAŘíK $^{5}$ \\ ${ }^{1}$ Prosetická 239, CZ-415 01 Teplice, Czech Republic; sutara@centrum.cz \\ ${ }^{2}$ Ondř́čckova 29, CZ-130 00 Praha 3, Czech Republic; janda.vaclav@gmail.com \\ ${ }^{3}$ National Museum, Mycological Department, Cirkusová 1740, CZ-193 00 Praha 9, Czech Republic; \\ mmartin.kriz@seznam.cz \\ ${ }^{4}$ Gregorova 16, CZ-702 00 Ostrava, Czech Republic; michalgraca.optik@gmail.com \\ ${ }^{5}$ Institute of Microbiology ASCR, Vídeňská 1083, CZ-142 20, Praha 4, Czech Republic; \\ mkolarik@biomed.cas.cz \\ *corresponding author
}

Šutara J., Janda V., Kříž M., Graca M., Kolařík M. (2014): Contribution to the study of genus Boletus, section Appendiculati: Boletus roseogriseus sp. nov. and neotypification of Boletus fuscoroseus Smotl. - Czech Mycol. 66(1): 1-37.

The paper deals with Boletus roseogriseus and Boletus fuscoroseus, two closely related species of the genus Boletus, section Appendiculati. B. roseogriseus is described as a new species based on a morphological and molecular study of collected material. B. fuscoroseus, validly published by Smotlacha in 1912, has been often incorrectly named Boletus pseudoregius. This name, however, does not have priority because $B$. pseudoregius was validly published as late as 1988 . In order to contribute to clarification of some controversial questions concerning B. fuscoroseus, the authors have selected a neotype for this species. Descriptions of B. roseogriseus and B. fuscoroseus are accompanied by results of a molecular study (ITS and LSU rDNA sequences) and a discussion of characters distinguishing these species from other representatives of section Appendiculati.

Key words: Boletus roseogriseus sp. nov., Boletus fuscoroseus, morphology, molecular phylogeny, neotypification, distribution.

Šutara J., Janda V., Křřž M., Graca M., Kolařík M. (2014): Příspěvek ke studiu rodu Boletus sekce Appendiculati: Boletus roseogriseus sp. nov. a neotypifikace druhu Boletus fuscoroseus Smotl. - Czech Mycol. 66(1): 1-37.

Článek se zabývá druhy Boletus roseogriseus (hřib šedorůžový) a Boletus fuscoroseus (hřib růžovník), dvěma blízce př́buznými hřiby rodu Boletus, sekce Appendiculati. B. roseogriseus je na základě morfologického a molekulárního studia sbíraného materiálu popsán jako nový druh. B. fuscoroseus, platně publikovaný Smotlachou v r. 1912, bývá často nesprávně pojmenován jako Boletus pseudoregius. Toto jméno však nemá prioritu, protože $B$. pseudoregius byl platně publikován až v r. 1988. Aby přispěli k vyjasnění některých sporných otázek týkajících se druhu $B$. fuscoroseus, vybrali autoři pro tento druh neotyp. Popisy druhů B. roseogriseus a $B$. fuscoroseus jsou doprovázeny výsledky molekulárního studia (ITS a LSU rDNA sekvencí) a diskuzí o znacích odlišujících tyto druhy od ostatních zástupců sekce Appendiculati. 


\section{INTRODUCTION}

In August 2008, during the mycological study of a locality near the village of Francova Lhota in East Moravia (Czech Republic), M. Graca found a very interesting bolete. The bolete was collected by M. Graca and some of his colleagues in the vicinity of Francova Lhota several times in subsequent years. Long-time observation and detailed study of the collected material showed that this bolete has several distinctive characters. Despite of this fact, however, we have not been able to identify it with any species known to date. For this reason, we describe this bolete as a new species, Boletus roseogriseus, based on our morphological and molecular study in this paper. The species belongs to Boletus Fr., section Appendiculati Konrad \& Maubl. ex Lannoy \& Estadès.

Boletus fuscoroseus Smotlacha also belongs to the section Appendiculati together with other European boletes such as Boletus regius Krombh., B. appendiculatus Schaeff., B. subappendiculatus Dermek, Lazebníček \& Veselský, and B. fechtneri Velen. Boletus fuscoroseus is one of the rarest boletes in the Czech Republic, very rare or uncommon in many other European countries, and does probably not occur in northern Europe (not listed in Knudsen \& Taylor 2012). It is somewhat more common only in the Mediterranean area (Italy, France, Spain). In mycological literature, this species is often cited as Boletus pseudoregius (Huber) Estadès (see e.g. Alessio 1991, Lannoy \& Estadès 2001, 2004, Redeuilh \& Simonini 2002, Watling \& Hills 2005, Muñoz 2005) or as Boletus speciosus sensu Singer (see e.g. Pilát \& Dermek 1974, Engel et al. 1983, Breitenbach \& Kränzlin 1991, Hagara et al. 1999). The name B. fuscoroseus was used for this species, by e.g. Velenovský (1922), Vacek (1954), Klofac (2007), Šutara et al. (2009), Kibby (2012), and Assyov (2012).

B. fuscoroseus has been studied by the authors for many years, including its distribution in the Czech Republic. The question of the correct name for B. fuscoroseus and features distinguishing this species from the related boletes are discussed in detail here.

\section{MATERIAL AND METHODS}

The results presented in this paper are based on a macro- and microscopic study of material of B. roseogriseus and B. fuscoroseus collected in 1998-2013. Material of other European boletes of section Appendiculati was studied for comparison.

Microscopic characters of the studied material were examined predominantly on dried specimens. Sections from dried material were mounted both in Melzer's 
reagent and in a 3-10\% solution of ammonium hydroxide $\left(\mathrm{NH}_{4} \mathrm{OH}\right)$ with (or without) Congo Red and examined under C. Zeiss Primo Star iLED and Meopta D816Bi microscopes with an oil immersion lens at a magnification of up to $1250 \times$. Drawings of microscopic characters (see Figs. 11 and 20) were made free hand. In order to ascertain the variability of the microscopic characters of some anatomical structures and their changes in the course of development, these structures were examined on both young and mature fruit bodies from several localities. Also spore sizes were measured on several fruit bodies from different localities (always at least 20 spores of every fruit body). In the results, the main range of $90 \%$ of the measured values is presented. The main data range is complemented by extreme spore sizes of very small (probably immature) and extremely large spores, which are presented in parentheses. Abbreviations: $\mathrm{Q}=$ spore length/width ratio; $\mathrm{Q}_{\mathrm{av}}=$ average value of $\mathrm{Q}$ of all spores studied.

Data on geological conditions were taken from maps and descriptions at www.geologicke-mapy.cz (Bokr on-line).

DNA was isolated from 14 dried specimens according to Holec \& Kolařík (2013). The ITS-LSU rDNA gene was amplified using primers ITS1F-KYO2 and NL4. The same primers, together with primers ITS4S and NL1 (Toju et al. 2012, O'Donnell 1993), were used for sequencing. The reaction mixtures, PCR settings and sequencing were according to Pažoutová et al. (2012). The EMBL accession numbers are listed in Tab. 1. Sequence selection followed Li et al. (2014) and separate ITS and LSU rDNA datasets were created. Both datasets were combined with the closest matches from the NCBI GenBank database (Tab. 1). Boletus calopus (ITS rDNA) and B. billieae and B. bicolor var. borealis (LSU rDNA), taxon sisters to the "Regius" clade in Nuhn et al. (2013), were selected for outgroups. Sequence alignments were obtained using MAFFT 6 (http://mafft.cbrc.jp/alignment/software; Katoh \& Toh 2008). Maximum likelihood (ML) analyses were performed using PhyML 3.0 (Guindon et al. 2010) and bootstrap support was obtained using 500 replicates. Evolutionary models were determined for all datasets using MEGA 5.2.1 (Tamura et al. 2011). See Figs. 1 and 2 for other details.

\section{RESULTS AND DISCUSSION}

\section{MOLECULAR STUDY}

The ITS rDNA alignment of the five studied Boletus roseogriseus specimens showed one variable position. $B$. roseogriseus had the longest ITS rDNA sequence (712 bp) when compared to other species (Fig. 1), whose full length varied from 606 to $695 \mathrm{bp}$. Its length is mostly caused by the guanine monomer at the position 
Tab. 1. List of sequences used in the phylogenetic analyses.

\begin{tabular}{|c|c|c|c|c|c|}
\hline Species & Location & Collection No. & ITS rDNA & LSU rDNA & Reference \\
\hline B. abieticola & - & CUW 26763 & & KF030268 & Nuhn et al. (2013) \\
\hline B. appendiculatus & Germany & JR 7012 & HQ882196 & JX290181 & Li et al. (2014) \\
\hline B. appendiculatus & Belgium & VD K0429 & HQ882194 & JX290179 & Li et al. (2014) \\
\hline B. appendiculatus & Belgium & BR Van Holen B.22 & HQ882193 & JX290178 & Li et al. (2014) \\
\hline B. appendiculatus & Czech Rep. & PRM 923472 & \multicolumn{2}{|c|}{ KJ419922 } & This study \\
\hline B. appendiculatus & Czech Rep. & PRM 923473 & KJ419923 & & This study \\
\hline B. bicolor var. borealis & USA & CUW 2858 & & JQ326998 & Halling et al. (2012) \\
\hline B. billieae & USA & CUW 4558 & & KF030265 & Nuhn et al. (2013) \\
\hline B. calopus & Portugal & MA-Fungi 41326 & AJ296293 & & Martín \& Moreno (2001) \\
\hline B. fechtneri & Germany & REG Bf1 & & AF456821 & Binder \& Bresinsky (2002) \\
\hline B. fechtneri & Czech Rep. & PRM 923468 & \multicolumn{2}{|c|}{ KJ419929 } & This study \\
\hline B. fechtneri & Czech Rep. & PRM 923469 & \multicolumn{2}{|c|}{ KJ419930 } & This study \\
\hline B. fechtneri & Spain & JAM 0360 & HM347652 & & Unpublished \\
\hline B. fechtneri & - & AT 2003097 & & KF030270 & Nuhn et al. (2013) \\
\hline B. floridanus & Costa Rica & BD 368 & JN020981 & HQ161859 & Dentinger et al. (2011) \\
\hline B. frostii & Mexico & MHM 069 & EU569285 & & Morris et al. (2008) \\
\hline $\begin{array}{l}\text { B. fuscoroseus (deposited } \\
\text { as } B \text {. pseudoregius) }\end{array}$ & Belgium & BR Lachapelle 2266.01 & JN903696 & KC111198 & Li et al. (2014) \\
\hline $\begin{array}{l}\text { B. fuscoroseus (deposited } \\
\text { as B. pseudoregius) }\end{array}$ & Belgium & $\begin{array}{l}\text { BR Omer Van de Kerckhove } \\
925\end{array}$ & JN903697 & KC111199 & Li et al. (2014) \\
\hline B. fuscoroseus & Czech Rep. & HR 86133 (neotype) & \multicolumn{2}{|c|}{ KJ419926 } & This study \\
\hline B. fuscoroseus & Czech Rep. & PRM 923474 & KJ419924 & & This study \\
\hline B. fuscoroseus & Czech Rep. & PRM 923475 & KJ419925 & & This study \\
\hline B. peckii & USA & CUW 3959 & & JQ326999 & Halling et al. (2012) \\
\hline B. pulchriceps & USA & DS 4514 & & KF030261 & Nuhn et al. (2013) \\
\hline B. regius & Germany & REG Bre1 & & DQ534653 & Binder \& Hibbett (2006) \\
\hline B. regius & USA & CUW 11265 & & KF030267 & Nuhn et al. (2013) \\
\hline B. regius & Czech Rep. & PRM 923465 & KJ419920 & KJ419931 & This study \\
\hline B. regius & Italy & MCVE 17387 & JF907788 & & Osmundson et al. (2013) \\
\hline $\begin{array}{l}\text { B. regius (deposited } \\
\text { as } B . \text { pseudoregius) }\end{array}$ & Spain & AAM 634/06 & FM958179 & & Unpublished \\
\hline $\begin{array}{l}\text { B. regius (deposited } \\
\text { as B.pseudoregius) }\end{array}$ & Portugal & UF 1409 & HM347661 & & Unpublished \\
\hline B. roseoflavus & China & HZFA 05801 (holotype) & GU233427 & JX290185 & Li et al. (2014) \\
\hline B. roseoflavus & China & HZFA 07901 & GU233428 & JX290184 & Li et al. (2014) \\
\hline B. roseogriseus & Czech Rep. & PRM 923483 (holotype) & \multicolumn{2}{|c|}{ KJ419927 } & This study \\
\hline B. roseogriseus & Czech Rep. & PRM 923481 & KJ419933 & & This study \\
\hline B. roseogriseus & Czech Rep. & PRM 923482 & KJ419934 & & This study \\
\hline B. roseogriseus & Czech Rep. & PRM 923479 & \multicolumn{2}{|c|}{ KJ419928 } & This study \\
\hline B. roseogriseus & Czech Rep. & PRM 923480 & \multicolumn{2}{|c|}{ KJ419932 } & This study \\
\hline B. speciosus & USA & TENN 28301 & HQ882206 & JX290186 & Li et al. (2014) \\
\hline B. speciosus & USA & TENN 42159 & HQ882207 & JX290187 & Li et al. (2014) \\
\hline B. subappendiculatus & Austria & WU 4729 & JN903698 & KC111200 & Li et al. (2014) \\
\hline B. subappendiculatus & Austria & WU 18328 & JN903699 & KC111201 & Li et al. (2014) \\
\hline B. subappendiculatus & Czech Rep. & PRM 923477 & \multicolumn{2}{|c|}{ KJ419921 } & This study \\
\hline
\end{tabular}




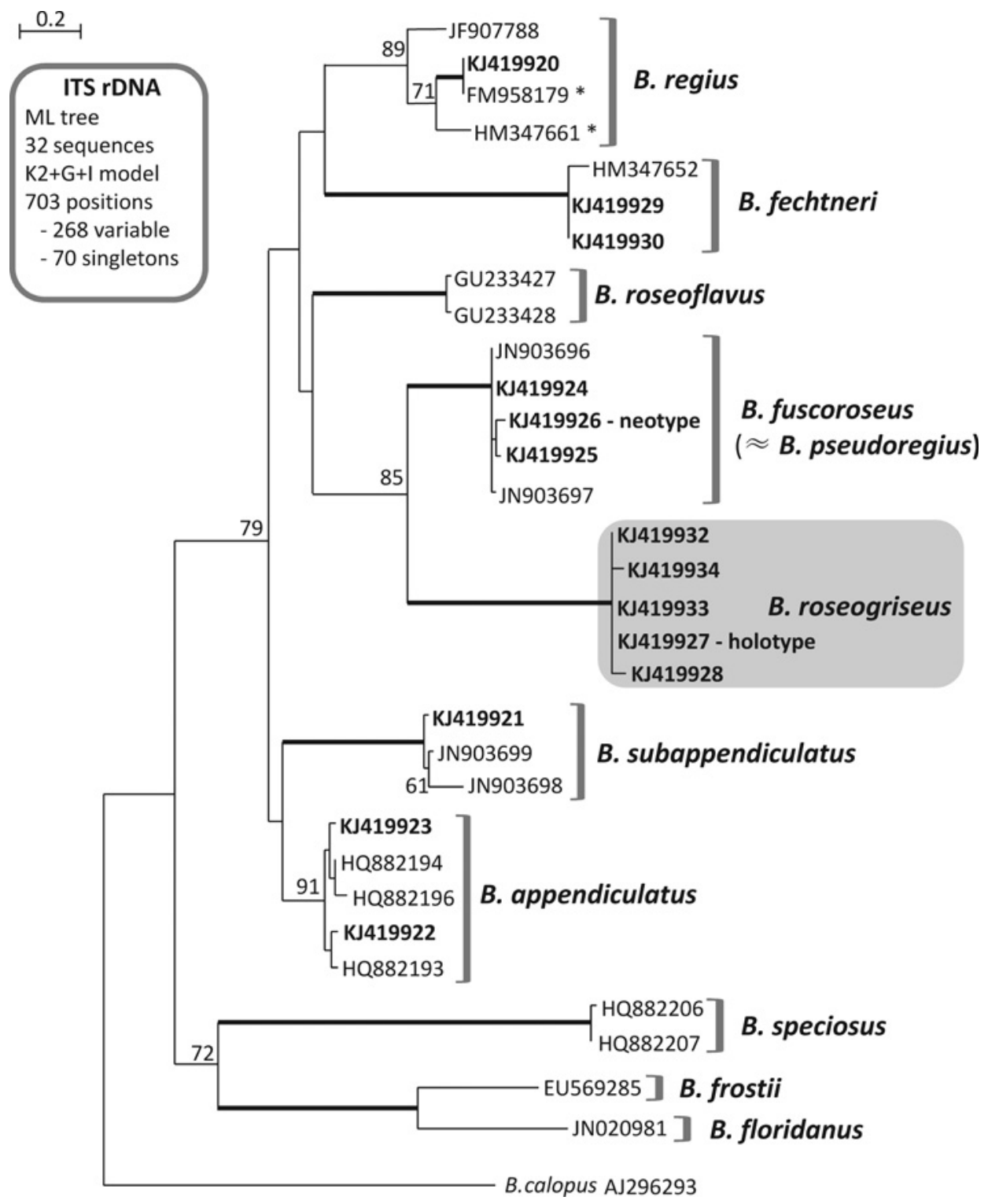

Fig. 1. Phylogenetic placement of Boletus roseogriseus inferred from ITS rDNA data. The best tree resulting from heuristic maximum-likelihood analysis in PHYML is presented. Statistical support for each node greater than $50 \%$ is shown. The branches with $100 \%$ bootstrap support are thickened. Sequences printed in bold were obtained during this study. Sequences marked with an asterisk were deposited in NCBI Genbank as B. pseudoregius (see Results and discussion for details). 


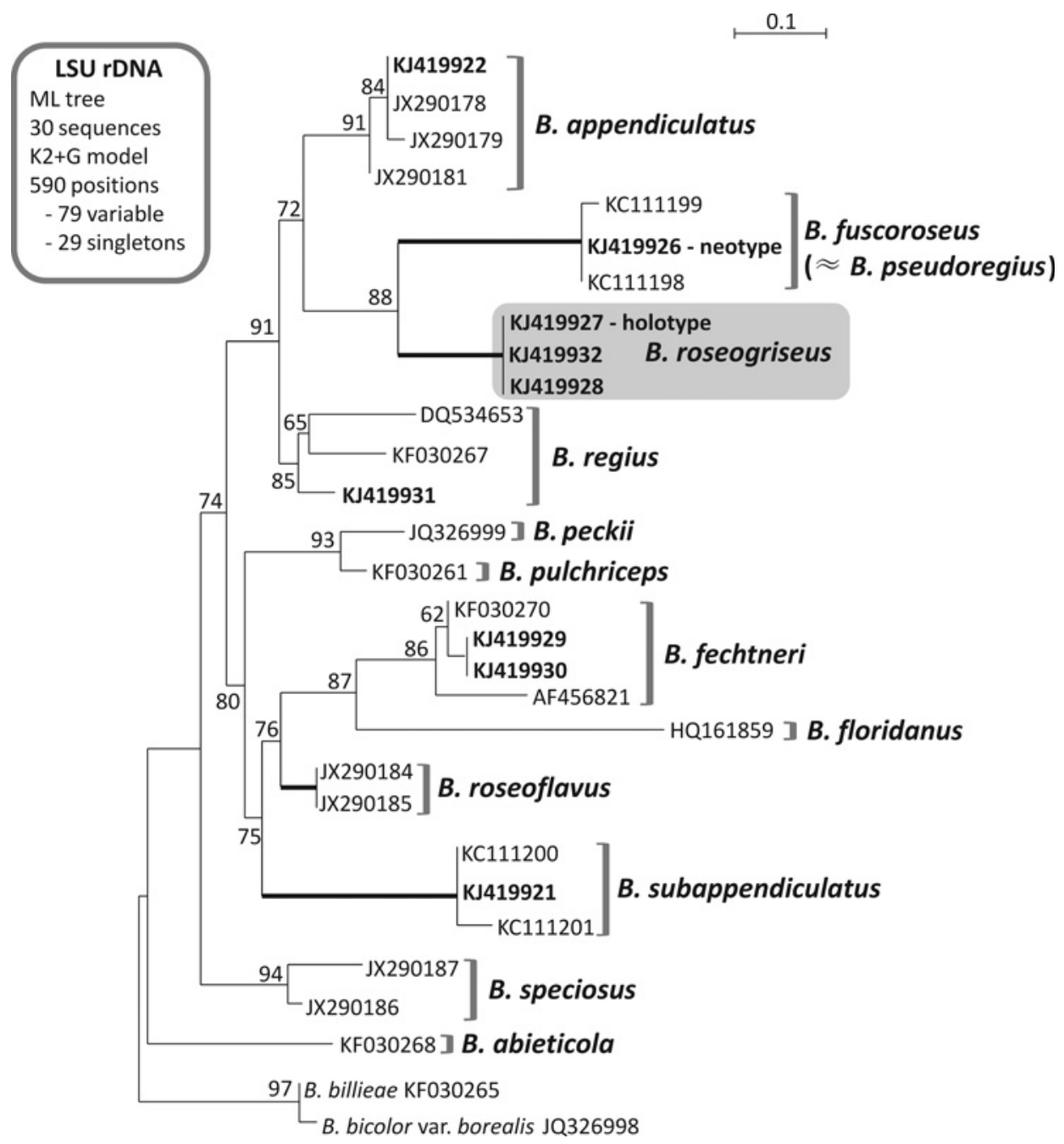

Fig. 2. Phylogenetic placement of Boletus roseogriseus inferred from LSU rDNA data. The best tree resulting from heuristic maximum-likelihood analysis in PHYML is presented. Statistical support for each node greater than $50 \%$ is shown. Branches with $100 \%$ bootstrap support are thickened. Sequences printed in bold were obtained during this study.

67-81, which was responsible for sequencing problems. The most similar sequences based on the BlastN similarity search of ITS and LSU rDNA belonged to various B. fuscoroseus specimens (deposited as B. pseudoregius) with similarity 91\% in ITS (e.g. JN903696) and 98\% in LSU rDNA (e.g. KC111199). Phylogenetic analyses of both rDNA gene datasets showed that $B$. roseogriseus formed a well- 
supported sister group to B. fuscoroseus. LSU-based phylogeny provided better statistical support for deeper branches and enabled recognition of two separate lineages consisting of $B$. speciosus and B. abieticola, a group containing $B$. roseogriseus, B. pseudoregius, B. appendiculatus and B. regius, and the group containing the rest of the species (Figs. 1, 2).

Our specimens were placed into groups with sequences published by Binder \& Bresinsky (2002), Li et al. (2014) and Nuhn et al. (2013) in agreement with their morphological identification. The LSU rDNA sequence of the Czech $B$. regius specimen clustered with $B$. regius sequences obtained from Germany and US material by Binder \& Hibbett (2006) and Nuhn et al. (2013). The ITS rDNA of the same Czech specimen belonged to a clade containing an Italian specimen identified as B. regius (JF907788, Osmundson et al. 2013) as well as unpublished sequences (FM958179, FM958185, FM958181, HM347661) from Spanish and Portuguese material deposited under the name B. pseudoregius. Li et al. (2013) used these unpublished sequences, together with other original material, and recognised two well-supported clades of $B$. pseudoregius sequences. We showed that one of them, represented by sequences FM958179 and HM347661, is in fact B. regius.

\section{TAXONOMY}

Boletus roseogriseus Šutara, Graca, M. Kolařík, Janda \& Kř́ž sp. nov. Figs. 3-11 (MycoBank MB808333)

Diagn o sis. Pileus 70-120(155) mm in diam., fleshy, mat, velutinous to subtomentose, becoming finely floccose-granulose at times, often pruinose when young. Coloration rather variable, at least partly pinkish when young, later with prevailing greyish, ochreous or brown tints, but often with remnants of a pinkish or reddish colour at the pileus margin up to maturity. Subcuticular layer pink or reddish when young, later changing to brown. Tubes yellow, with faint olivaceous shade with age. Pores concolorous, small, roundish. Both pores and tubes blueing or blue-greening when bruised. Stipe light or vivid yellow, with a distinct, yellow reticulation in the whole above-ground part. Context yellow or light yellowish in pileus, apex and surface layer of stipe, pale yellowish or whitish in middle part of stipe, brownish in stipe base; blueing in pileus and stipe apex when exposed. Taste and smell pleasant. Pileipellis a filamentous trichoderm formed by hyphae 3-8.5 $\mu \mathrm{m}$ wide, without a conspicuous incrustation. Trama of hymenophore bilateral, boletoid. Spores of boletoid shape, smooth under a light microscope, (11.0)12.0-14.5(16.7) × (4.8)5.2-6.5(7.5) $\mu \mathrm{m}, \mathrm{Q}_{\mathrm{av}}=2.31$. Stipe covered with a caulohymenium with sporulating caulobasidia. Growing in fir or fir-spruce forests, on the ground under Abies alba, in submountainous region.

Boletus roseogriseus, belonging to Boletus sect. Appendiculati, differs from the most closely related B. fuscoroseus above all by the absence of reddish tints in the coloration of the stipe, its somewhat different coloration of pileus without purplish brown shades, the brownish context in the lower part of its stipe, its growth under Abies in submountainous forests, a very slight or no incrustation of the pileus cuticle hyphae, and broader spores [for comparison, in B. fuscoroseus the spores are (4.1)4.4-5.1(5.9) $\mu \mathrm{m}$ broad and $\mathrm{Q}_{\mathrm{av}}=2.61$ ]. Characters distinguishing B. roseogriseus from other boletes of sect. Appendiculati are discussed below - see Distinguishing characters. 
Hol oty p e: Czech Republic, East Moravia, Javorníky Mts., ca. $1 \mathrm{~km}$ SE of the village of Francova Lhota, forest plantations covering NW slopes of Tisůvek and Čubův kopec hills, alt. 580-595 m, under Abies, Picea and Corylus, 13 Aug. 2010, leg. Michal Graca, det. Josef Šutara, Michal Graca, Václav Janda, Martin Kříž \& Miroslav Kolařík. Holotype deposited in the National Museum, Prague (PRM 923483), isotype in the Moravian Museum, Brno (BRNM 761689).

Ety m ol ogy. Derived from lat. "roseus" = pink and "griseus" = grey.

\section{Description}

Macros copic characters. Pileus 70-120(155) mm in diam. when mature, at first almost hemispherical, then convex to plano-convex or pulvinate, sometimes with uneven surface and irregularly wavy margin when young. Cuticle mat, mostly subtomentose, less frequently velutinous, occasionally becoming very finely floccose-granulose with age, often pruinose when young. Coloration of pileus rather variable, changing during development and sometimes influenced by weather conditions, light pink, medium pink (rarely even reddish pink in some places), greyish pink, grey (at times with a grey-olivaceous shade particularly at the top of pileus), greyish brown, ochreous, pale brown, medium brown to deep brown. Pinkish tints, best developed in young developmental stages (see Figs. 3-7), later gradually fade away, so that the grey, ochreous or brown shades gradually predominate in further stages (see Figs. 8-10), nevertheless the pinkish or reddish tints long remain at least in marginal pileus zone, often up to maturity. Subcuticular context layer pink or reddish when young, gradually changing to brown with age. Bruised places on pileus of young fruit bodies becoming immediately pink or red (see Fig. 7), then very slowly brown. Places bitten by slugs or other animals becoming very slowly orange-red, deep red or dark vinaceous red, finally brown to dark brown.

Tub e s up to $20 \mathrm{~mm}$ long, somewhat depressed around stipe apex, sometimes slightly decurrent with small tooth when mature, vivid yellow from youth to maturity, with faint olivaceous shade with age. Pores vivid yellow or golden yellow, at first closed, then minute, roundish, at most 0.8(1) mm large when mature. Both pores and tubes blueing or blue-greening when bruised or cut.

Sp ore-print not obtained (probably brown with olivaceous tint as in other species of section Appendiculati).

Stip e up to $90 \mathrm{~mm}$ long and $50 \mathrm{~mm}$ broad, vivid yellow overall, sometimes light yellow in lower part, more or less clavate, at times almost fusiform, obtuse or tapering at base, sometimes with small, up to 10(15) mm long appendix. Aboveground part of stipe covered with yellow, well-developed reticulation. Stipe surface blueing when bruised. Places bitten by slugs (after initial blue oxidation) sometimes becoming red to vinaceous red and finally rust-brown. Basal tomentum predominantly white or whitish, at times greyish, grey-olivaceous or slightly rust-coloured in some places. 


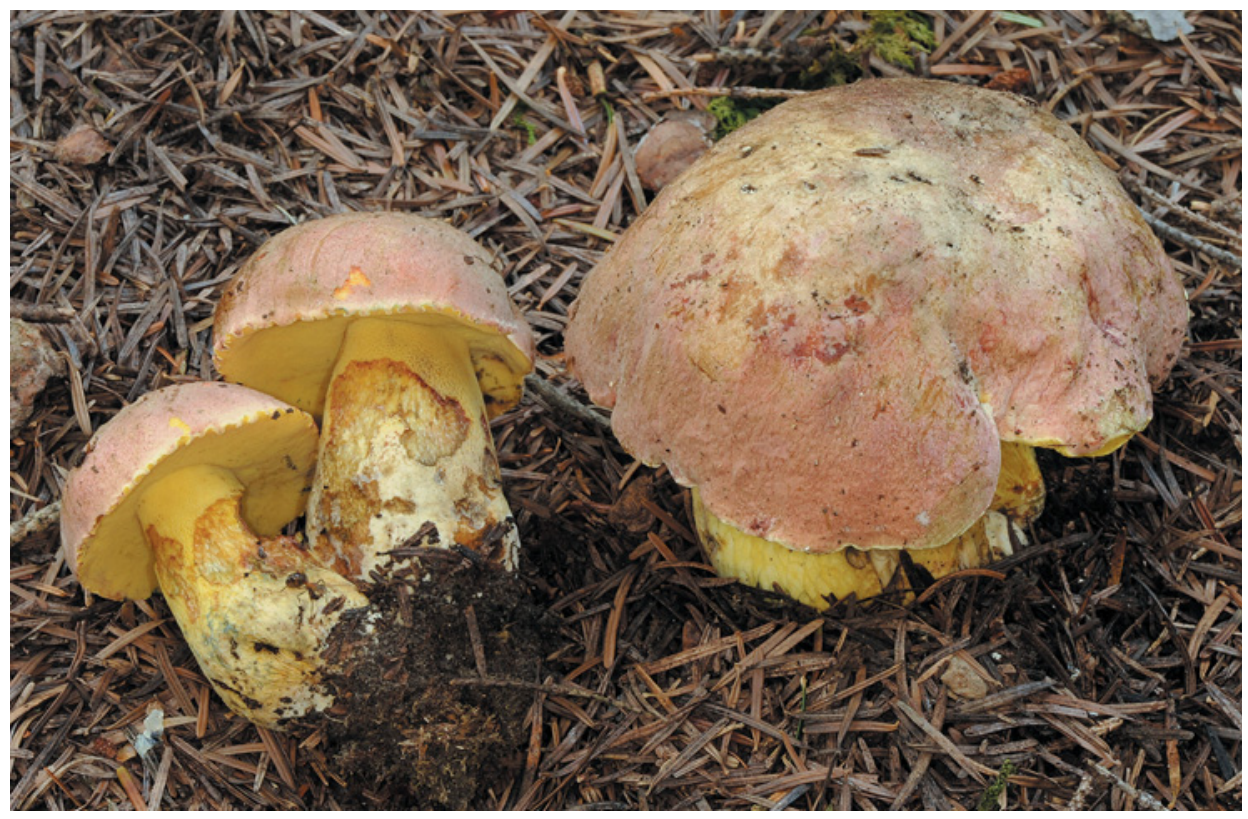

Fig. 3. Boletus roseogriseus, Czech Republic, Francova Lhota, north-western slopes of Tisůvek and Čubův kopec hills, under Abies, Picea and Corylus, 13 Aug. 2010 (holotype PRM 923483). Photo M. Graca.

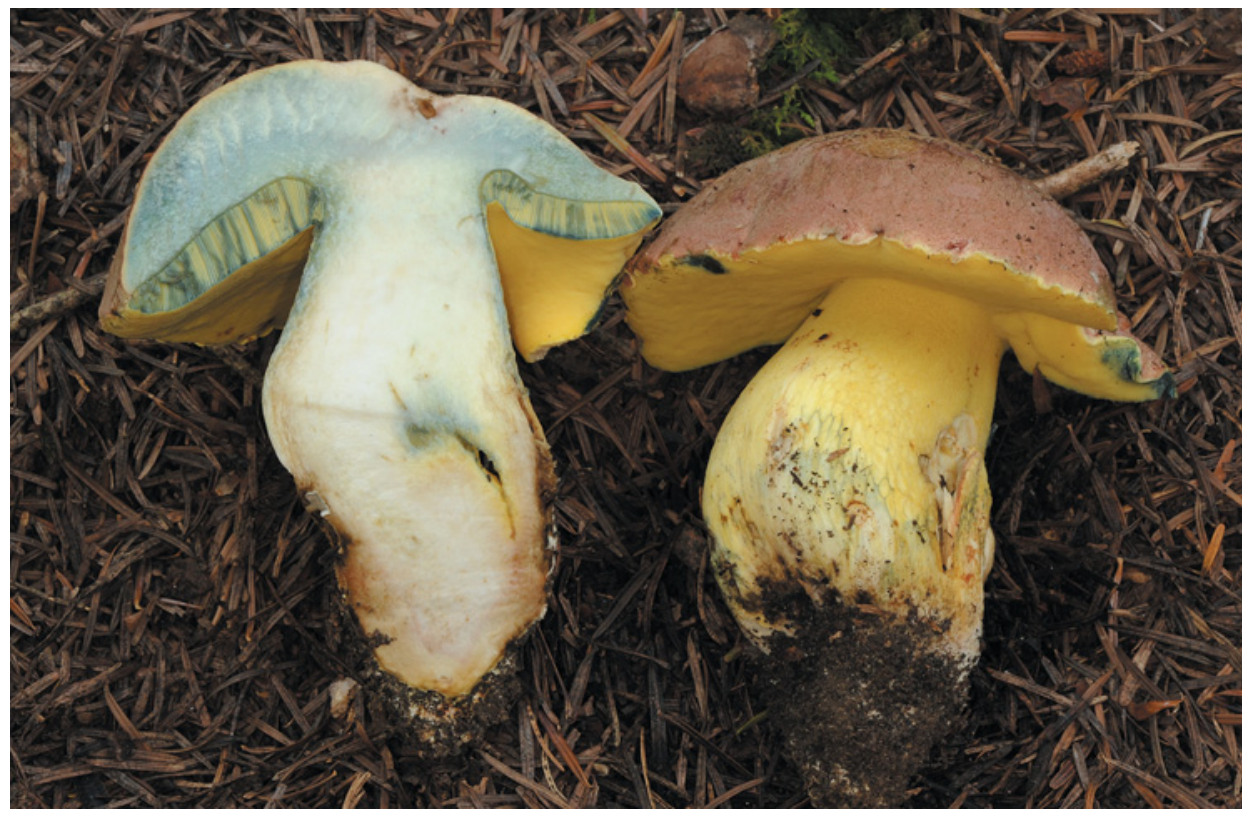

Fig. 4. Boletus roseogriseus, Czech Republic, Francova Lhota, north-western slopes of Tisůvek and Čubův kopec hills, under Abies, Picea and Corylus, 13 Aug. 2010 (holotype PRM 923483). Photo M. Graca. 


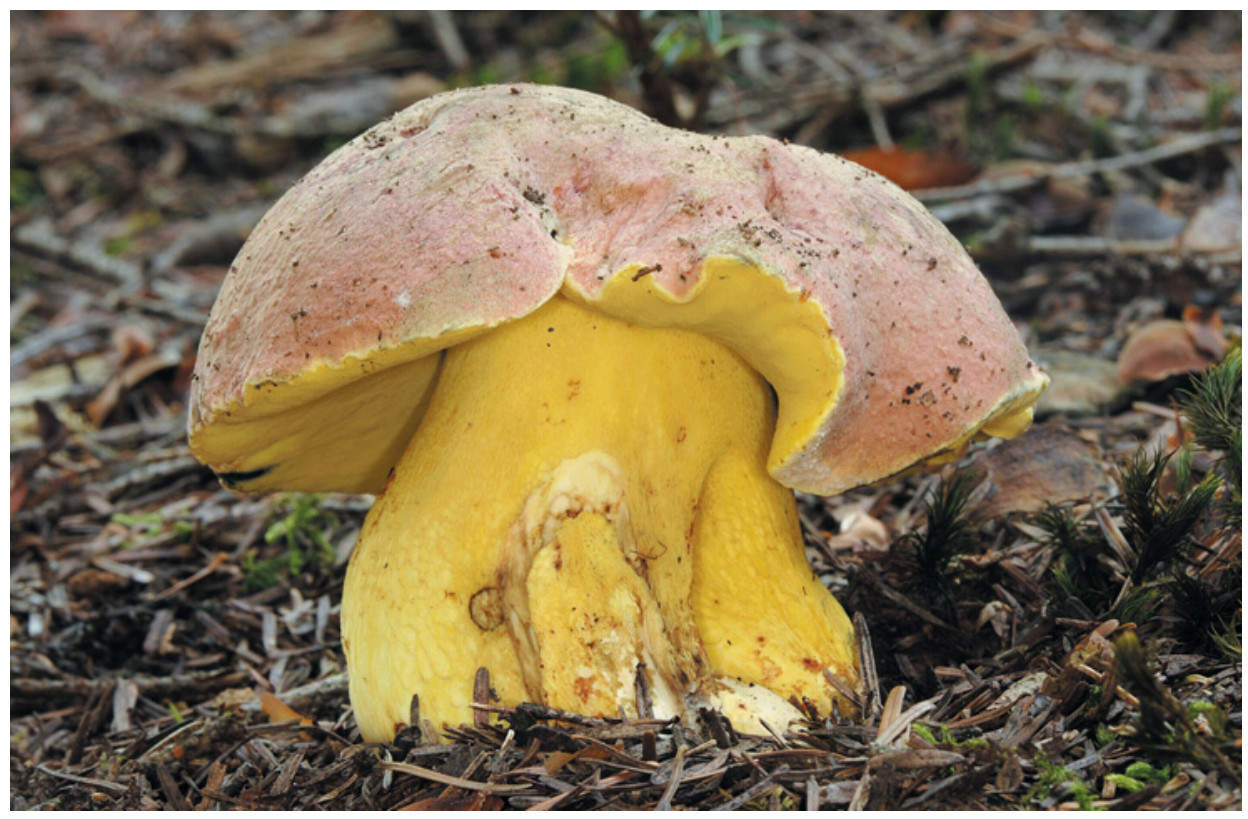

Fig. 5. Boletus roseogriseus, Czech Republic, Francova Lhota, north-western slopes of Tisůvek and Čubův kopec hills, under Abies, Picea and Corylus, 13 Aug. 2010 (holotype PRM 923483). Photo M. Graca.

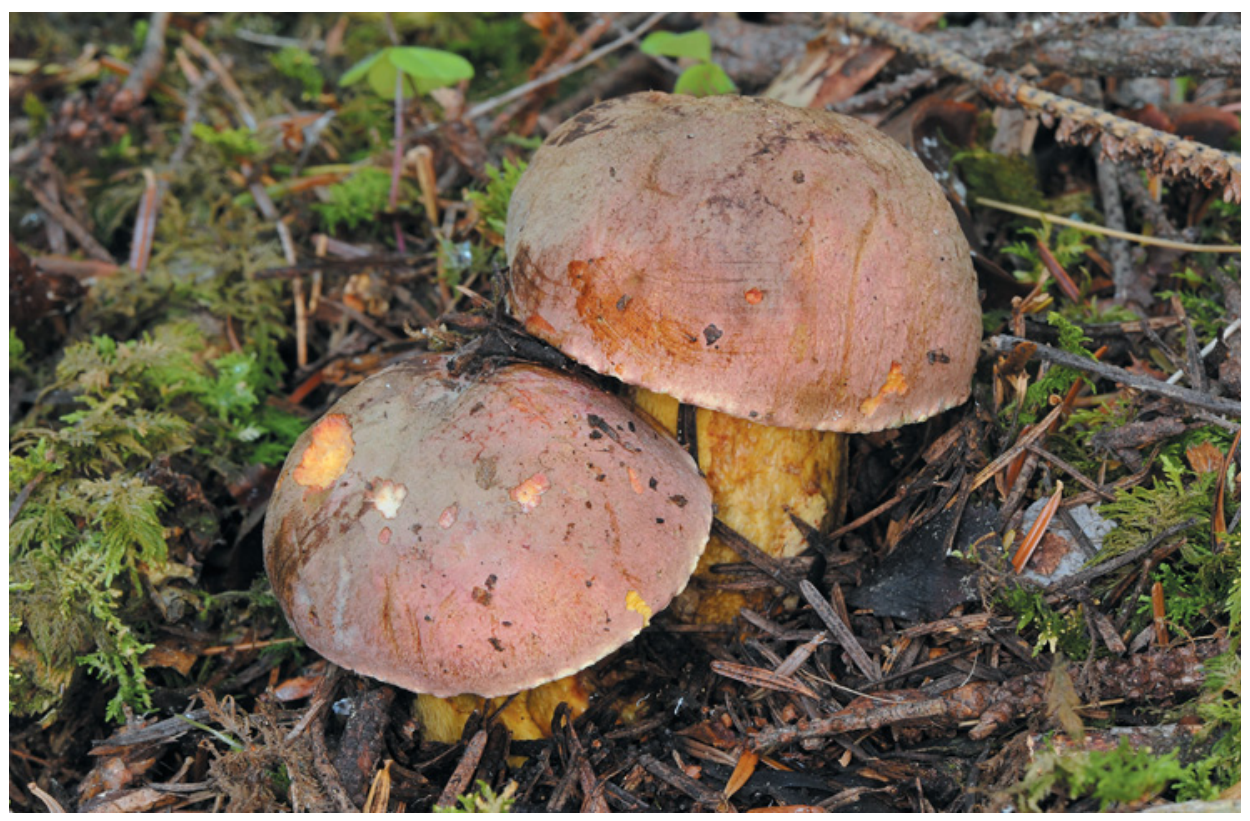

Fig. 6. Boletus roseogriseus, Czech Republic, Francova Lhota, north-western slopes of Tisůvek and Čubův kopec hills, under Abies, Picea and Corylus, 13 Aug. 2010 (holotype PRM 923483). Photo M. Graca. 


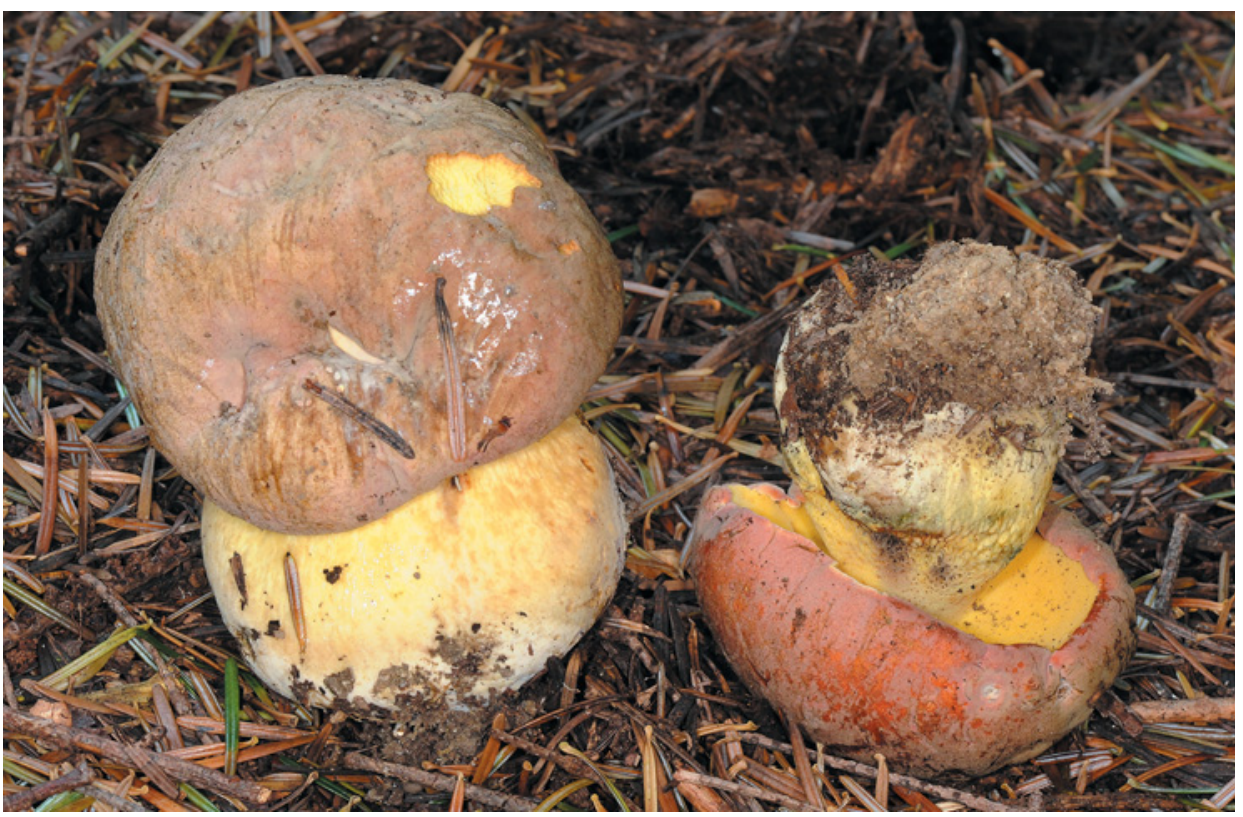

Fig. 7. Boletus roseogriseus, Czech Republic, Francova Lhota, north-western slopes of Tisůvek and Čubův kopec hills, under Picea and Abies, 8 Aug. 2012 (PRM 923481). Photo M. Graca.

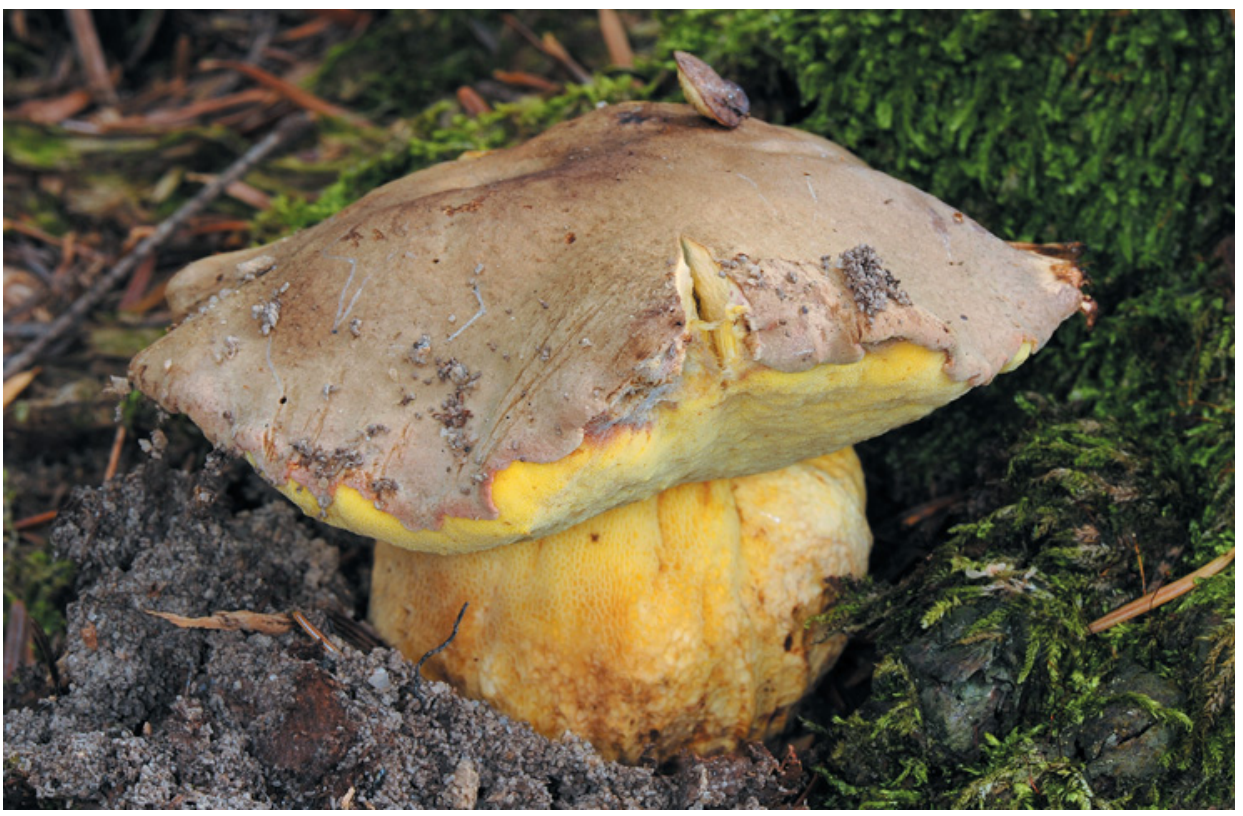

Fig. 8. Boletus roseogriseus, Czech Republic, Francova Lhota, north-western slopes of Tisůvek and Čubův kopec hills, under Abies, Picea and Corylus, 17 Aug. 2012 (PRM 923482). Photo M. Graca. 


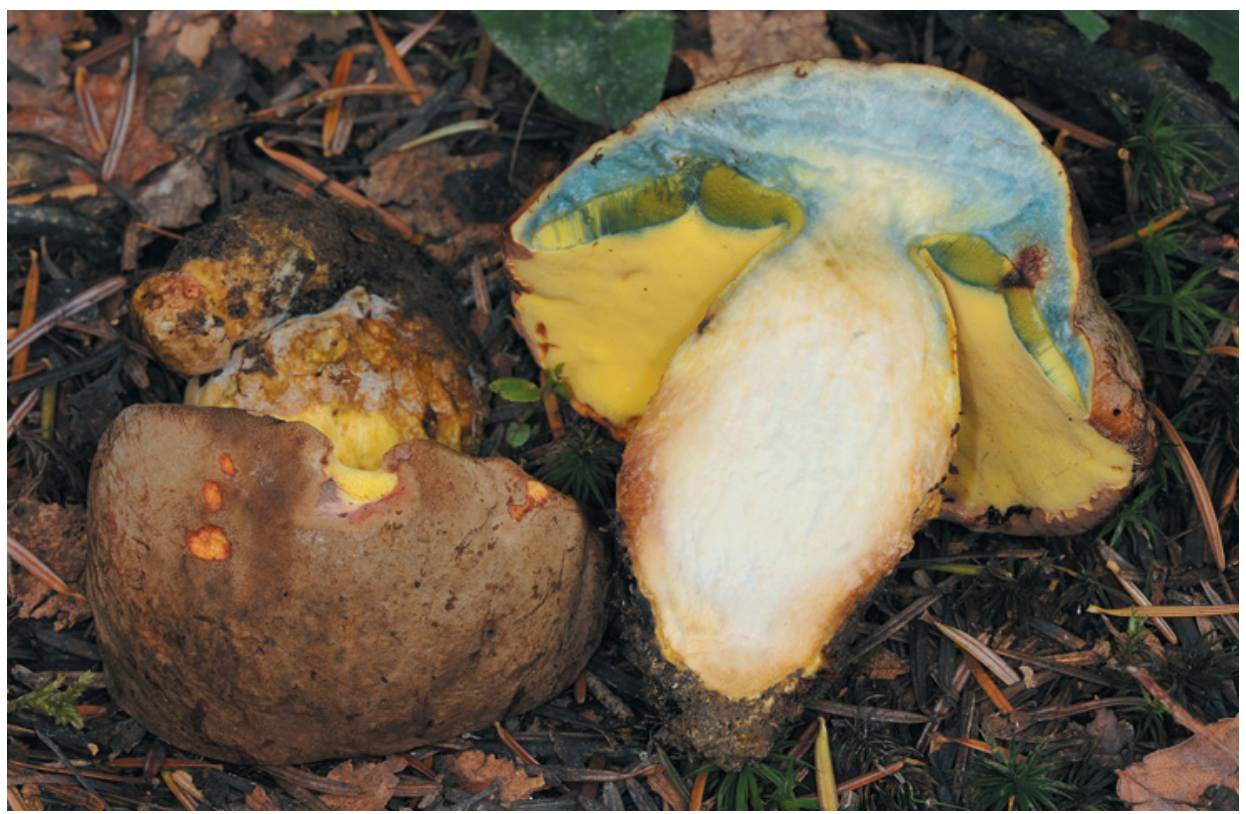

Fig. 9. Boletus roseogriseus, Czech Republic, Francova Lhota, north-western slopes of Tisůvek and Čubův kopec hills, under Abies, Picea and Betula, 18 Aug. 2010 (JŠ 6192). Photo M. Graca.

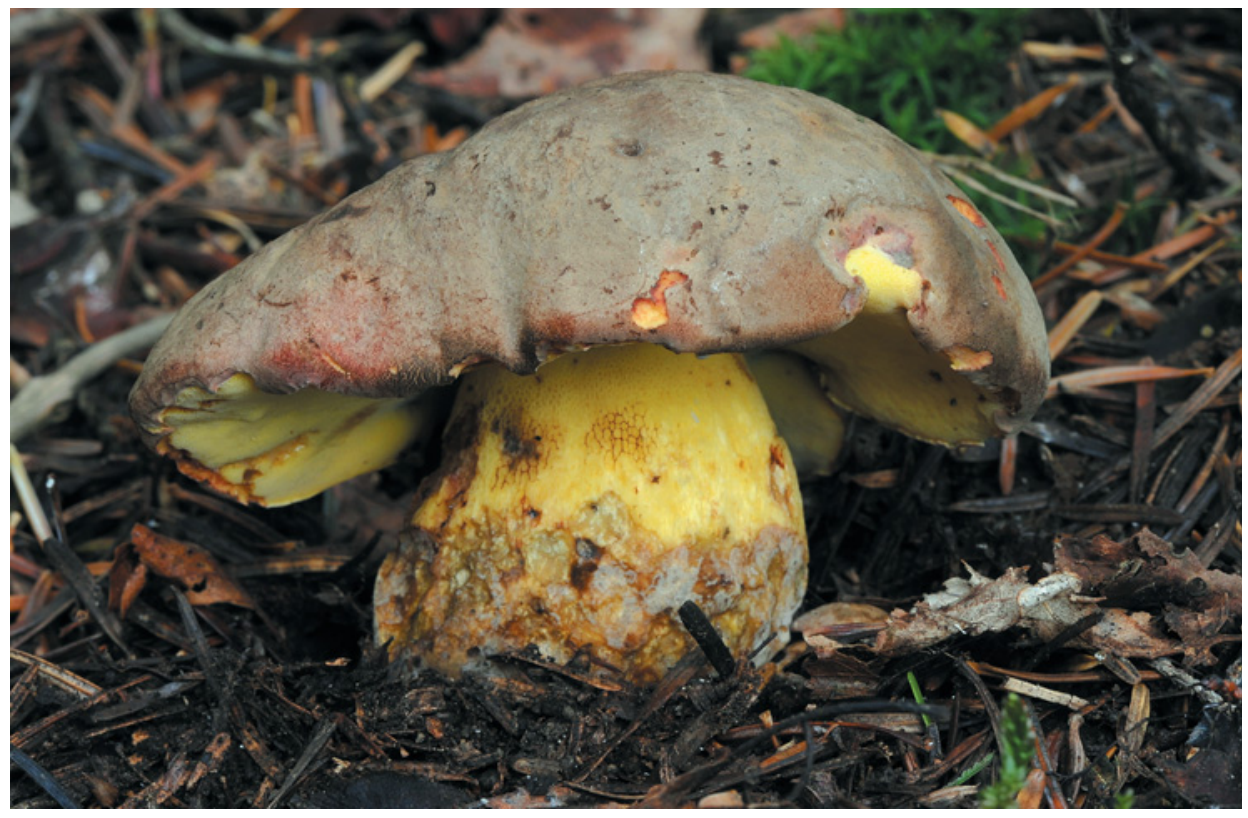

Fig. 10. Boletus roseogriseus, Czech Republic, Francova Lhota, north-western slopes of Tisůvek and Čubův kopec hills, under Abies, Picea and Betula, 18 Aug. 2010 (JŠ 6193). Photo M. Graca. 
C on text yellow or light yellowish in pileus, upper part and surface layer of stipe, whitish in middle part of stipe, brownish in lower part of stipe. Context of pileus and stipe apex staining blue when cut or bruised. Colour of tunnels of insect larvae reddish or brownish. Taste mild; smell mushroomy, pleasant.

Microscopic characters. Pileus cuticle (pileipellis) a filamentous trichoderm (Fig. 11a) composed of hyphae (3)4-7(8.5) $\mu \mathrm{m}$ broad, with walls thin and mostly smooth or almost smooth, merely in a very small number of trichodermal elements with inconspicuous, very weak incrustation appearing as fine asperulation of hypha surface. Trichoderm consisting of layer of predominantly anticlinally arranged hyphae in young developmental stage, however trichodermal hyphae sometimes partly collapsing or clustering into small tufts (looking like very minute, floccose granules or subtomentose squamulae under magnifying glass) in later stages. Trichodermal hyphae in young fruit bodies usually with colourless or slightly greyish content in pure water, very slightly yellowish, dispersed or dissolved, often entirely transparent in Melzer's reagent. In further developmental stages hypha content mostly changing to brown and, in some cases, becoming partly amorphous or finely granulose.

Hymenophore. Hymenophoral trama of younger and middle-aged fruit bodies bilateral, true boletoid, composed of densely arranged mediostratum intensively red when stained with Congo-Red and two gelatinous, divergent, loosely arranged lateral strata, colourless or almost colourless in Congo-Red solution. Basidia (Fig. 11c) mostly 4-spored, clavate or clavate-capitate, 28-44.5 × 8.5-12.5 $\mu \mathrm{m}$, with content dispersed or dissolved and often partly granular or multiglobular. Pleurocystidia (Fig. 11d) uncommon, scattered, smooth and thin-walled, fusiform, elongate-fusiform, fusiform-rostrate or lageniform, 32-52 × 6-10 $\mu \mathrm{m}$. Cheilocystidia (Fig. 11e) very abundant, of various shape, from almost cylindrical or subclavate to fusiform, fusiform-rostrate or lageniform, (27)30-61 × (4)7-12.5 $\mu \mathrm{m}$, smooth and thin-walled, with inconspicuous, pale yellowish, dissolved or dispersed content in Melzer's reagent.

Sp or e s (Fig. 11b) of boletoid shape, fusoid-ellipsoid, with suprahilar depression in side view, smooth under light microscope, (11.0)12.0-14.5(16.7) $\times$ (4.8)5.2-6.5(7.5) $\mu \mathrm{m}, \mathrm{Q}=(1.95) 2.20-2.42(2.57), \mathrm{Q}_{\mathrm{av}}=2.31$, yellowish to brownish in Melzer's reagent.

Stipe. Above-ground part of stipe covered with a fertile caulohymenium. Caulobasidia (Fig. 11f, g) 32-42 × (7)8.5-14 $\mu \mathrm{m}$, mostly 4-spored, rather abundant in upper part of stipe, sparsely scattered in lower stipe part, clavate or clavatecapitate, with dissolved or dispersed and often partly granular or multiglobular content. Caulocystidia (Fig. 11h) of various shape, e.g. subcylindrical, subclavate, fusiform, fusiform-ventricose, fusiform-rostrate or lageniform, abundant particu-

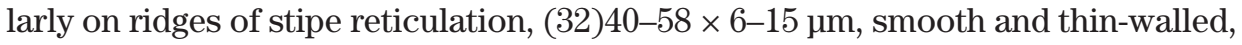
with a dispersed or dissolved, pale yellowish content in Melzer's reagent. Lateral 


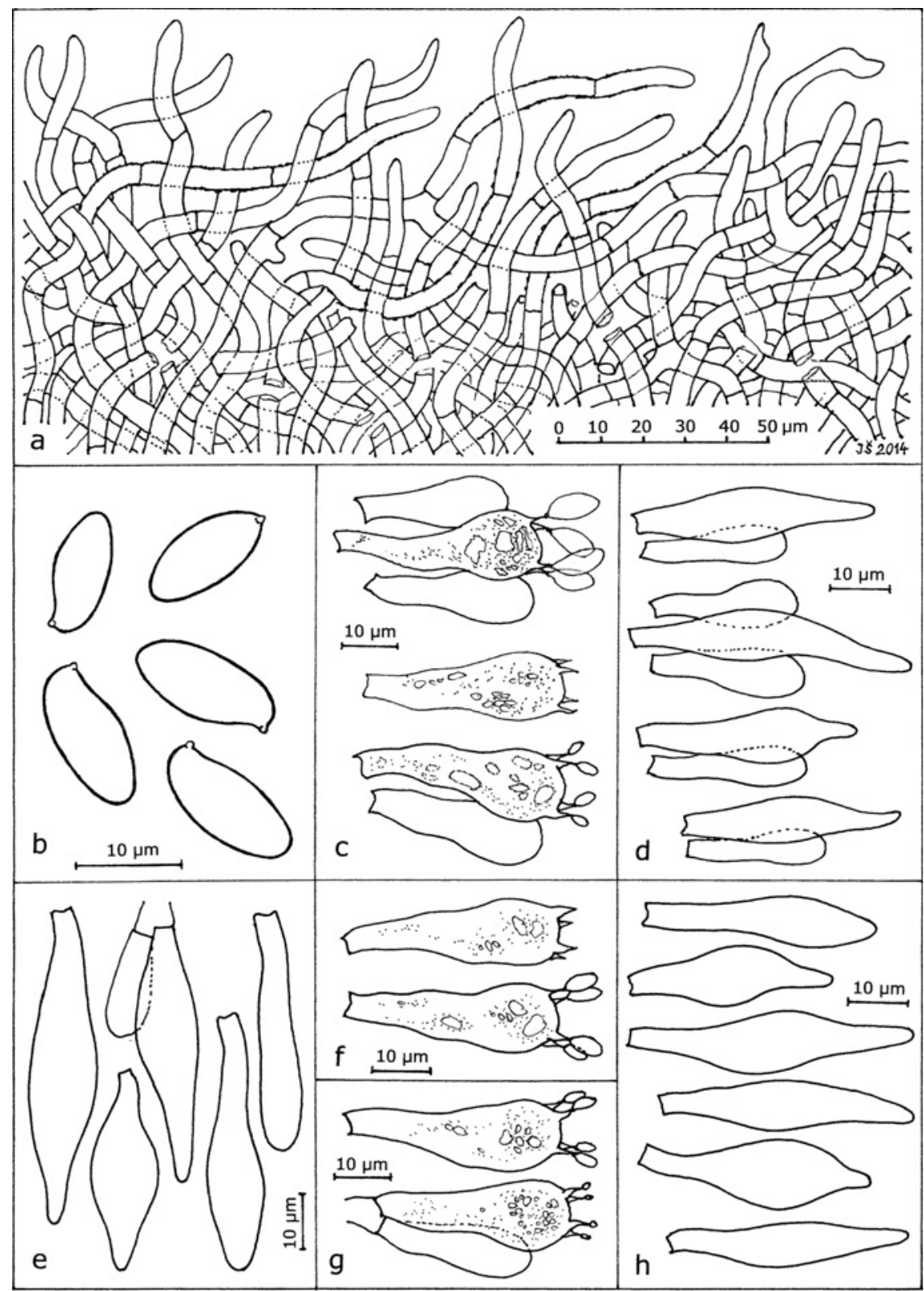

Fig. 11. Boletus roseogriseus: a - pileipellis in radial section showing trichoderm on margin of pileus of young fruit body; a few trichodermal hyphae have an asperulate surface and a very weak incrustation (JŠ 6192); b - spores (PRM 923483 holotype, JŠ 6191); c - basidia of hymenophore (PRM 923483 holotype, JŠ 6191); d - pleurocystidia (PRM 923483 holotype, JŠ 6191); e - cheilocystidia (PRM 923483 holotype); f-caulobasidia in upper half of stipe (JŠ 6188); $\mathbf{g}$ - caulobasidia in lower part of stipe (PRM 923483 holotype); $\mathbf{h}$ - caulocystidia (JŠ 6188). Del. J. Šutara. 
stipe stratum distinctly developed particularly in upper part of stipe, loosely arranged, composed of divergently arranged, (3)4-6(8) $\mu \mathrm{m}$ broad hyphae. Thickness of lateral stipe stratum (35)40-55 $\mu \mathrm{m}$ between ridges of reticulation, up to $85(100) \mu \mathrm{m}$ in trama of ridges (for definition of 'lateral stipe stratum', see Šutara 2005).

C o n t ext of pileus consisting of loosely and irregularly intertwining filamentous and somewhat broadened hyphae 3-15(20) $\mu \mathrm{m}$ wide, smooth and thinwalled, slightly yellowish in pure water, with yellowish, inconspicuous, dispersed or dissolved content in Melzer's reagent. Context of upper and middle part of stipe consisting of filamentous and somewhat broadened hyphae densely and almost regularly arranged more or less parallel with the longitudinal stipe axis, 4-21 $\mu \mathrm{m}$ wide, content yellowish, dispersed or dissolved in Melzer's reagent. Hyphae in stipe base 4-14 $\mathrm{mm}$ wide, arranged in a less regular way than in other parts of stipe, content dissolved, dispersed, granular or partly amorphous, yellowish, yellow-brownish or orange-brown in Melzer's reagent. Hyphae with 'oily' content occurring in pileus, hymenophore and stipe (including pileus cuticle, hymenophoral trama, and surface layers of stipe). Reaction with Melzer's reagent non-amyloid in all parts and microscopic elements of fruit body. Clamp connections not found in fruit body.

\section{Ecology and distribution}

E c ology. In middle-aged to old fir or fir-spruce forests under trees of Abies alba, sometimes with admixture of Picea abies, on the ground, most frequently in litter of needles and twigs, sometimes among Vaccinium myrtillus. On sites of Boletus roseogriseus, scattered individuals of Corylus avellana, Pinus sylvestris, Populus tremula, Sorbus aucuparia, Betula pendula, Larix decidua, and Quercus robur occur, but obviously with no significance for the occurrence of this bolete. Because B. roseogriseus was found under Abies alba at all microlocalities, we assume that it is ectomycorrhizal with this tree species. Fruit bodies grow solitarily or in small groups from July to early October, the most numerously in August. The geological bedrock consists of claystone and sandstone of the West Carpathian flysch belt. The $\mathrm{pH}$ ranges from moderately alkaline to neutral or slightly acidic. The altitudes are in the range of 575 to $610 \mathrm{~m}$ a.s.l.

At the microlocalities of $B$. roseogriseus also other species of the genus $B o$ letus were found, e.g. B. luridiformis, B. edulis, B. rubrosanguineus, and $B$. torosus. Under conifers at these microlocalities, M. Graca even collected B. appendiculatus and B. reticulatus, species which usually grow under deciduous trees. This interesting finding could be a separate topic for a further study. Other interesting macromycetes occurring at the localities are e.g. Albatrellus cristatus, Cortinarius melanotus, Hygrophorus abieticola, H. capreolarius, 
Lactarius salmonicolor, Russula viscida, Tricholoma bufonium, T. pardinum, and Xerula melanotricha.

Distribution. Boletus roseogriseus is hitherto only known from a few microlocalities in the vicinity of the village of Francova Lhota (East Moravia, Czech Republic) - see Material examined and Fig. 19.

\section{Distinguishing characters}

Characters important to distinguish Boletus roseogriseus from other species of sect. Appendiculati can be summarised as follows.

(1) Pileus at least partly pinkish when young, later with prevailing greyish, ochreous or brown tints, but mostly with remnants of pinkish or reddish shades at margin up to maturity. Despite the fact that the coloration of the pileus of B. roseogriseus rather changes during development, it is sufficiently characteristic and helps distinguish this species from other boletes of sect. Appendiculati.

(2) Stipe yellow coloured, without pinkish or reddish tints.

(3) Context in stipe base brownish.

(4) Relatively deep blue oxidation of context and tubes.

(5) Growth under Abies in submountainous region.

(6) Very slight or no incrustation of hyphae in pileus cuticle.

(7) Relatively broad spores and a low spore length/width ratio $\left(\mathrm{Q}_{\mathrm{av}}\right)$. For comparison, the following spore measurements and $\mathrm{Q}_{\mathrm{av}}$ values were obtained from our microscopical examination of European species of sect. Appendiculati (in declining order of their $\mathrm{Q}_{\mathrm{av}}$ values): B. regius $(10) 11-14(16) \times 3.4-4.5(5) \mu \mathrm{m}, \mathrm{Q}_{\mathrm{av}}=$ 3.21 ; B. subappendiculatus (10.8)11.9-14(17) $\times 3.5-4.5(4.7) \mu \mathrm{m}, \mathrm{Q}_{\mathrm{av}}=3.16$; B. appendiculatus $(10.8) 11-14(15.5) \times(4) 4.3-5.1(5.5) \mu \mathrm{m}, \mathrm{Q}_{\mathrm{av}}=2.65 ;$ B. fuscoroseus (10)11-13.5(15.8) × (4.1)4.4-5.1(5.9) $\mu \mathrm{m}, \mathrm{Q}_{\mathrm{av}}=2.61 ;$ B. fechtneri (10)11.4-14.2(17.5) $\times(4.6) 5-6(6.7) \mu \mathrm{m}, \mathrm{Q}_{\mathrm{av}}=2.32 ;$ B.roseogriseus $(11) 12-14.5(16.7) \times(4.8) 5.2-6.5(7.5)$ $\mu \mathrm{m}, \mathrm{Q}_{\mathrm{av}}=2.31$.

B. fuscoroseus (Figs. 12-18) differs from B. roseogriseus by a pinkish or reddish zone on its stipe in most cases; a pinkish or carmine-rose context in the lower part of the stipe particularly when young; conspicuous incrustation of hyphae in pileus cuticle; its growth under deciduous trees, predominantly Quercus, in thermophytic regions. There is also a small, but distinct difference in pileus colour between B. fuscoroseus and B. roseogriseus. The pileus of B. fuscoroseus is brownish pink or reddish brown, but its pinkish or reddish shades often have a slight red-purplish component which does usually not occur in B. roseogriseus.

B. subappendiculatus (Fig. 24) differs from B. roseogriseus mainly by a light ochreous or pale brownish pileus coloration without pink or reddish tints; not blueing or only very slightly blueing pileus context and tubes; its distinctly narrower spores. 
B. fechtneri (Fig. 22) has the following characters different from B. roseogriseus: a whitish, whitish grey, greyish, silvery grey, grey-brown or brownish, sometimes slightly shiny pileus (beneath the pileipellis of B. fechtneri there is a subcuticular layer which is brown or brownish pink, but the brownish pink colour of this layer is usually seen only in a scalp or section of the pileus, so that it mostly has no distinct influence on the whitish, greyish or brownish surface coloration of pileus); an often pinkish or reddish zone on the stipe; a pinkish or carmine-rose context in the lower part of the stipe when young; its growth predominantly under deciduous trees, mostly Quercus, in thermophytic regions.

B. regius (Fig. 21) differs from B. roseogriseus by its pink, reddish pink or red pileus without brown or greyish shades; its context and tubes unchanging or only very sligthly blueing; growth under deciduous trees; narrower spores.

B. appendiculatus (Fig. 23) differs from B. roseogriseus mainly by its brown pileus coloration without pinkish or reddish tints; a more distinct incrustation of hyphae in the pileus cuticle; its somewhat narrower spores; and its growth predominantly under deciduous trees, mostly Quercus.

Boletus abieticola Thiers is a North American species having: "Pileus ... surface ... appressed fibrillose, forming more or less imbricated fibrillose scales that remain readily apparent even when dried, occasionally almost white; color light rose with tan-colored spots interspersed and appearing yellow under the scales ... context ... white to pale yellow, usually unchanging, occasionally slowly changing to blue in irregular areas when exposed ... Stipe ... yellow, reddish at base ... context white except reddish at the base, unchanging when exposed ... Spores 14-17.5 × 4.5-5.5 $\mathrm{\mu m}$..." (see Thiers 1975).

Boletus roseoflavus Hai B. Li \& Hai L. Wei, a Chinese species, was described having the following characters: "Pileus ... light pink, light purplish red to rose-red, slightly pinkish when mature ... Stipe ... purple red or brownish red at base ... Basidiospores $9-12 \times 3.5-4 \mu \mathrm{m} \ldots$ Growing in moist habitats ... under Pinus taiwanensis, P. massoniana, P. yunanensis, or mixed forest dominated by Pinus taiwanensis." (see Li et al. 2014).

From the above quotations taken from the original descriptions of B. abieticola and B. roseoflavus and from molecular data (Figs. 1, 2), it is obvious that these two species are not identical with $B$. roseogriseus. 
Boletus fuscoroseus Smotlacha in Monografie českých hub hřibovitých (Boletineí), Věstn. Král. Čes. Spol. Nauk 1911, no. 8: 47, 1912.

Figs. 12-18, 20

$=$ Boletus appendiculatus subsp. regius sensu Konrad in Bull. Soc. mycol. Fr. 41: 66, 1925, non orig. Boletus regius Krombholz 1832.

$=$ Boletus appendiculatus subsp. pseudoregius Huber (nom. invalidum) in Zeitsch. f. Pilzk. 22 (Alte Folge), 17 (Neue Folge): 87, 1938.

$=$ Boletus pseudoregius (Huber) ex Estadès in Bull. Féd. Myc. Dauphiné-Savoie No 108: 7, 1988.

= Boletus speciosus sensu Singer in Die Röhrlinge 2: 38, 1967, non orig. Frost 1874.

Selected illustrations. Engel et al. (1983): p. 77, fig. 17 (as B. speciosus); Hagara (1993): p. 127, fig. 39 (as B. speciosus); Galli (1998, 2007): p. 187-188, 189 fig. above (as B. pseudoregius); Schreiner (1998): p. 146, fig. 4 (as B. pseudoregius); Hagara et al. (1999): p. 342, fig. 11 (as B. speciosus); Gminder (2000): p. 240 (as B. pseudoregius); Muñoz (2005): p. 695-697, fig. 51 a-h (as B. pseudoregius); Marques \& Muñoz (2006): p. 359, fig. below (as B. pseudoregius); Šutara et al. (2009): p. 125-127 (as B. fuscoroseus); Assyov (2012): p. 413, fig. 3 and 4 (as B. fuscoroseus); Galli (2013): p. 189-190, 191 fig. above (as B. pseudoregius).

Holotype. None designated.

Other original material. No collection studied by Smotlacha has been preserved.

Ne otype (designated here) (MycoBank MBT177565): Czech Republic, East Bohemia, Horní Ředice near Holice, Žernov forest, on dam of Smilek pond, alt. 260 m, under Quercus robur, 6 Aug. 2010, leg. \& det. J. Kramoliš. Neotype deposited in the Museum of Eastern Bohemia, Hradec Králové (HR 86133), isoneotype deposited in the National Museum, Prague (PRM 923476).

As the neotype, we selected herbarium material collected in Žernov forest near Holice, which was cited by Smotlacha in his original description (see below). It is interesting that B. fuscoroseus still grows at this locality more than 100 years after Smotlacha's first find of this species. Both locality and morphological characters of the selected material fit the protologue.

Original description (written in Czech). Klobouk zprvu polokulovitý, později polštářovitý, 10-20 cm široký, barvy hnědé s růžovým nádechem. Trubky zprvu krátké, později prodloužené, 1-1¹/2 cm dlouhé, z počátku zjevně na třeň přecházející, později pouze připojené, žluté s ústími okrouhlými, úzkými, stejně jako trubky zbarvenými, po doteku mírně modrozelenajícími. Spory světle hnědé, elipsoidní, 10 u dlouhé, 3-4 u široké. Třeň 8-16 cm dlouhý, tuhý, plný, zprvu kuželovitý, dole břichatý, nahoře ztenčen, celý význačně sítkován, na povrchu při porušení nejprve modrozelenající, později špinavící. Dužnina plodnice tuhá, jemná, žlutobílá, při porušení modrající.

B. fuscoroseus jeví vztahy $\mathrm{k}$ oběma předešlým druhům. Odlišuje se však kuželovitým třeněm, trubkami zprvu sbíhajícími, mimo to od B. regius modráním dužniny a trubek, od B. aereus barvou klobouku. Chutí a povahou dužniny shoduje se s oběma druhy, jest jedlý a stejně cenný. Sbíral jsem jej poprvé v srpnu 1909 v lese Žernově u Holic pod duby. Dvě plodnice jeho poslal jsem na ukázku prof. Velenovskému. V okolí slove růžovník.

A shortened English translation of Smotlacha's original description (with explanatory notes in parentheses) is given below - see History and nomenclature.

\section{Description}

Macroscopic characters. Pileus at first hemispherical, then convex, finally plano-convex to pulvinate, with a regular, even margin, 50-120(140) $\mathrm{mm}$ wide, brown pink, reddish brown or purplish brown, sometimes with prevailing pinkish, reddish or purplish red tints but sometimes, on the contrary, with pre- 


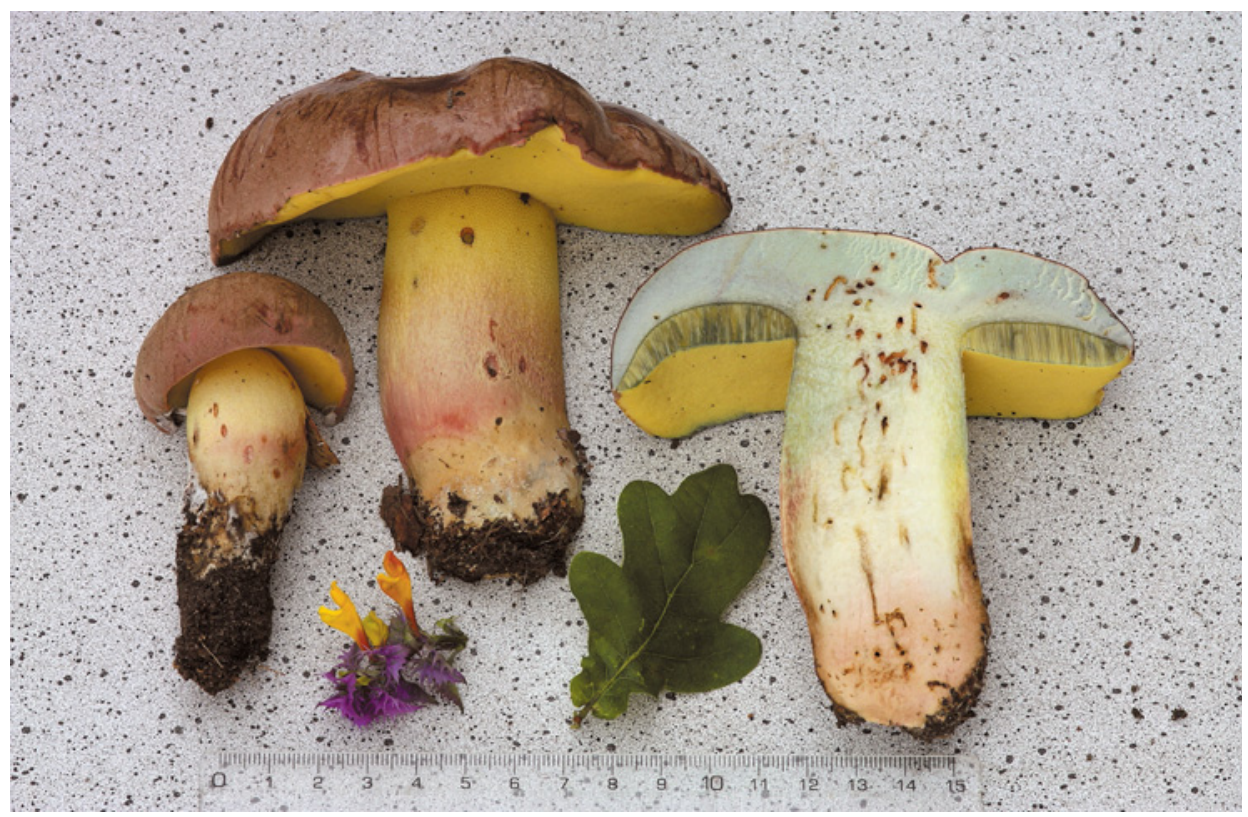

Fig. 12. Boletus fuscoroseus, Czech Republic, Horní Ředice near Holice, Žernov forest, under Quercus, 6 Aug. 2010 (neotype HR 86133, isoneotype PRM 923476). Photo J. Kramoliš.

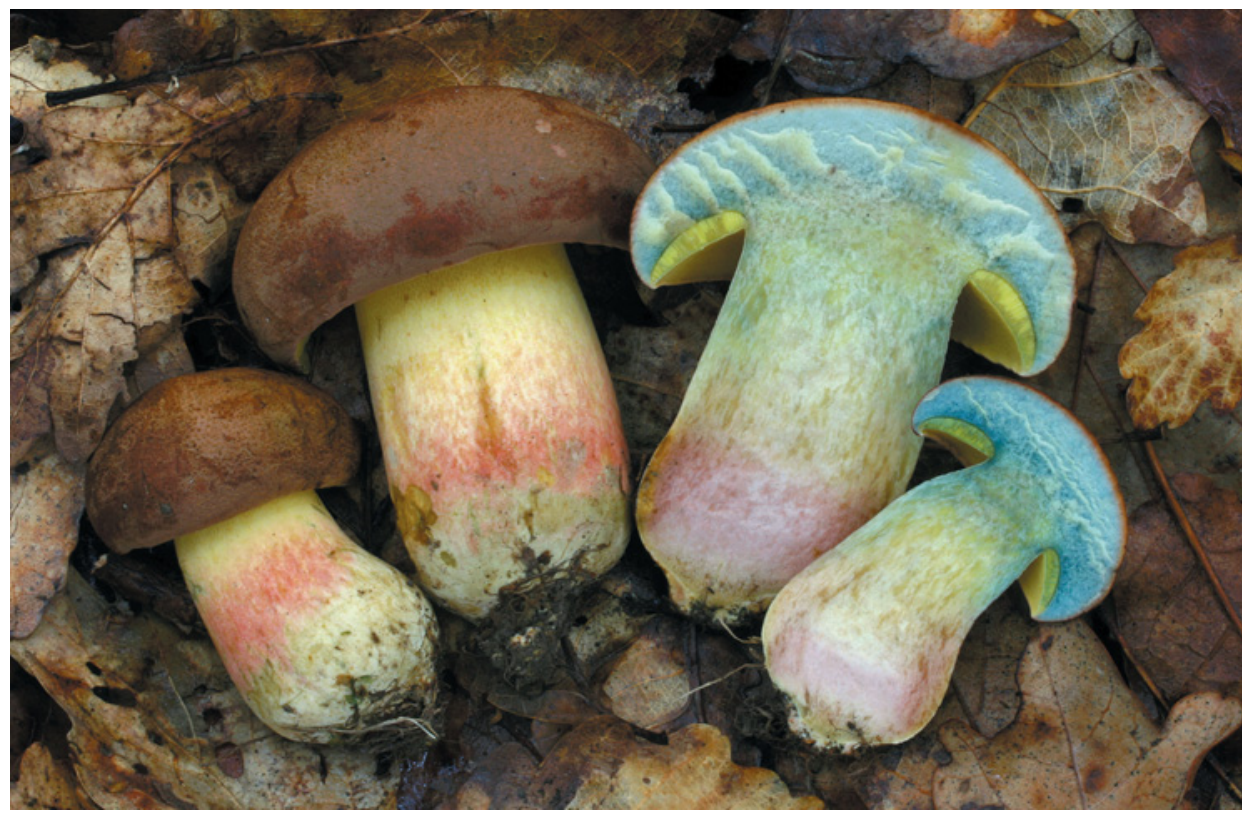

Fig. 13. Boletus fuscoroseus, Czech Republic, Běrunice, Kněžičky Game Preserve, under Quercus, 23 June 2009 (PRM 923475). Photo V. Janda. 
Czech Mycology 66(1): 1-37, June 4, 2014 (ONLINE VERSION, ISSN 1805-1421)

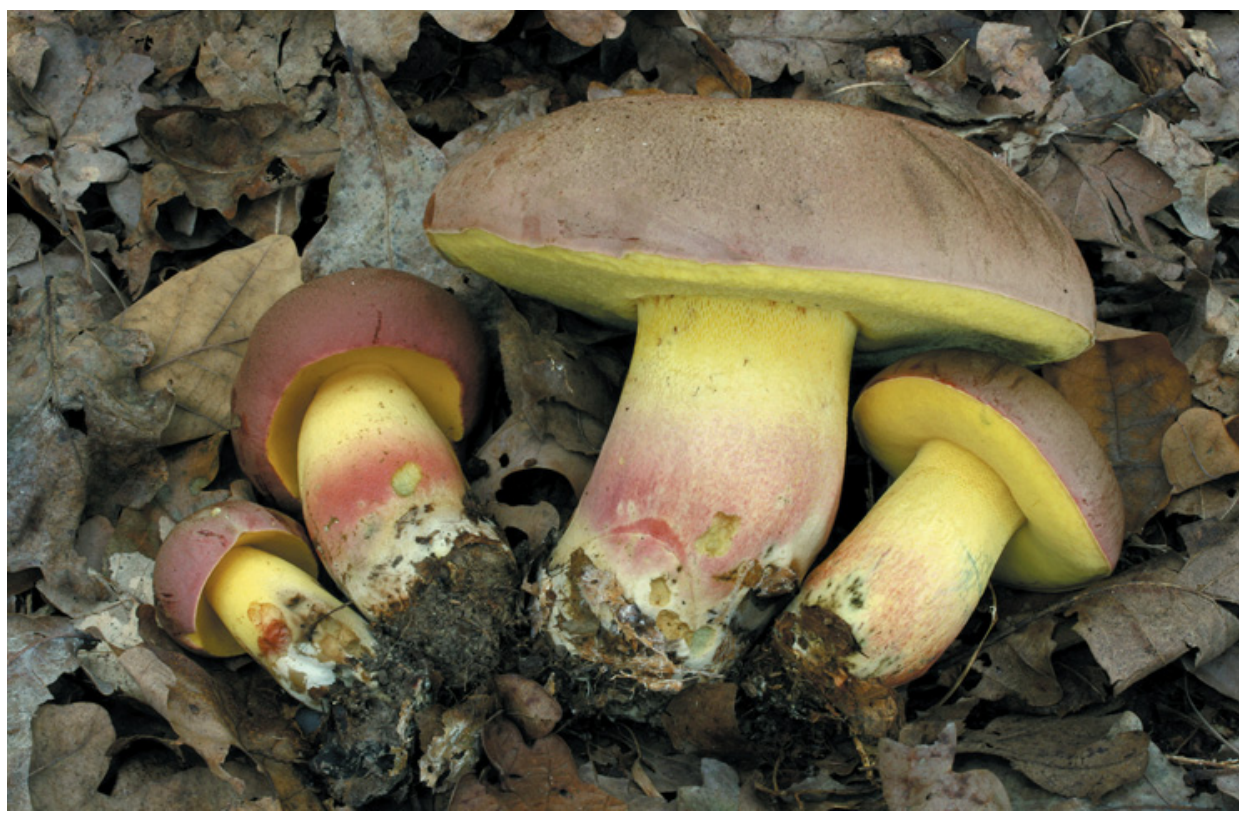

Fig. 14. Boletus fuscoroseus, Czech Republic, Běrunice, Kněžičky Game Preserve, under Quercus, 24 Sept. 2011 (PRM 923474). Photo V. Janda.

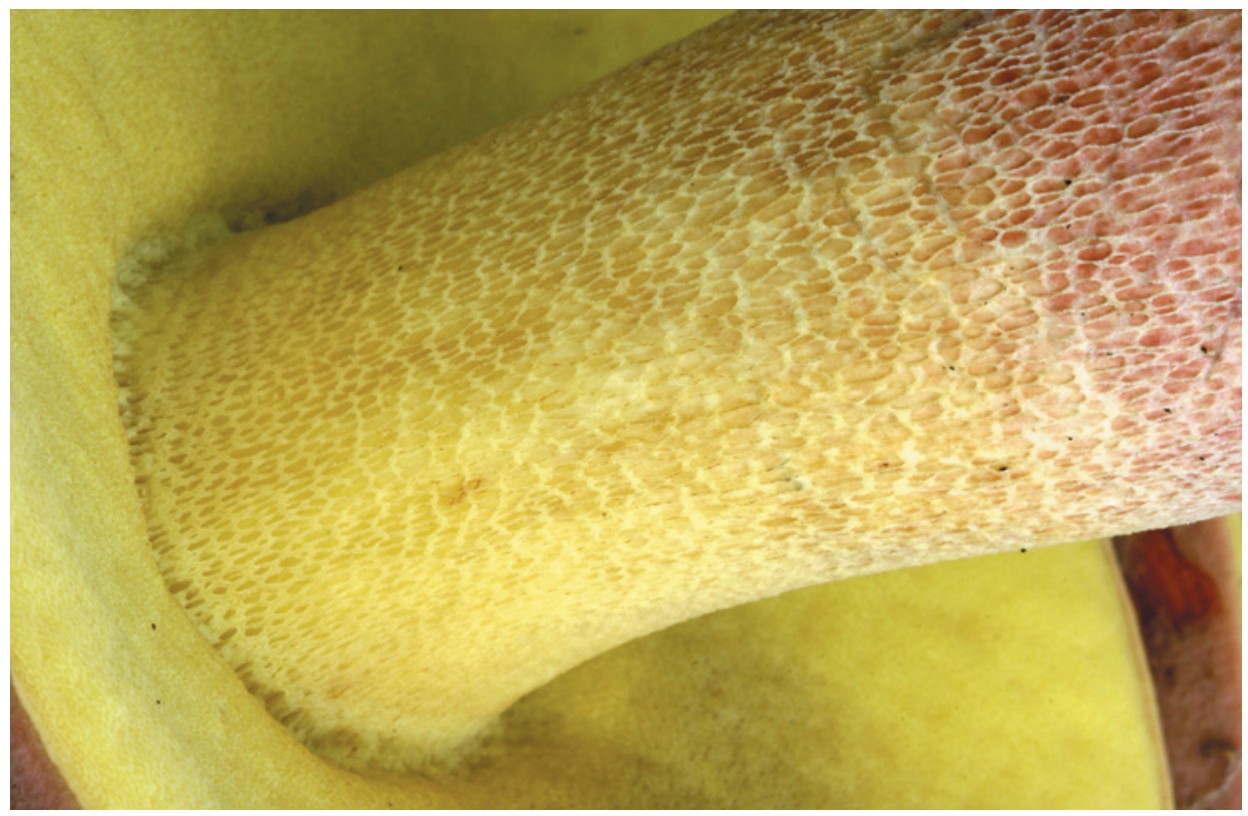

Fig. 15. Boletus fuscoroseus, Czech Republic, Běrunice, Kněžičky Game Preserve, under Quercus, 21 July 2009 (PRM 923678). Photo V. Janda. 


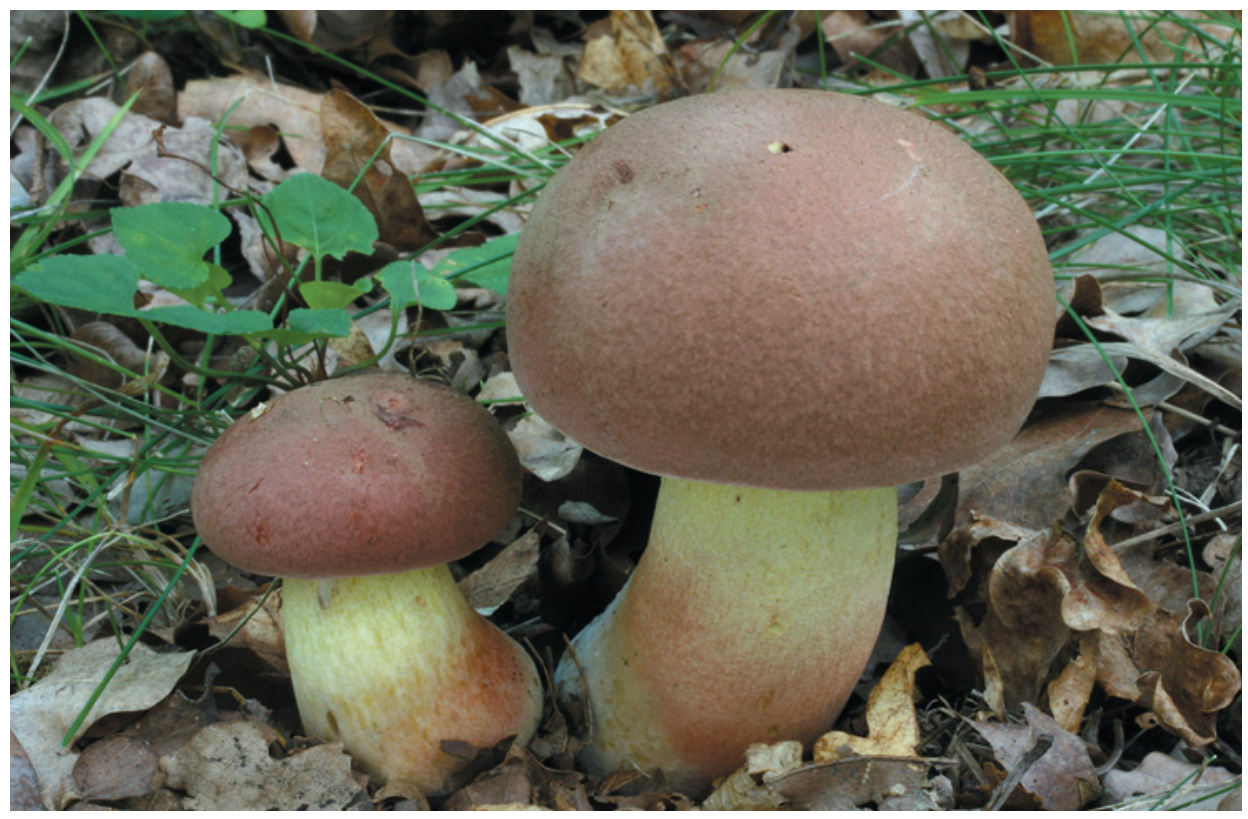

Fig. 16. Boletus fuscoroseus, Czech Republic, Běrunice, Kněžičky Game Preserve, under Quercus, 23 July 2009 (PRM 923679). Photo V. Janda.

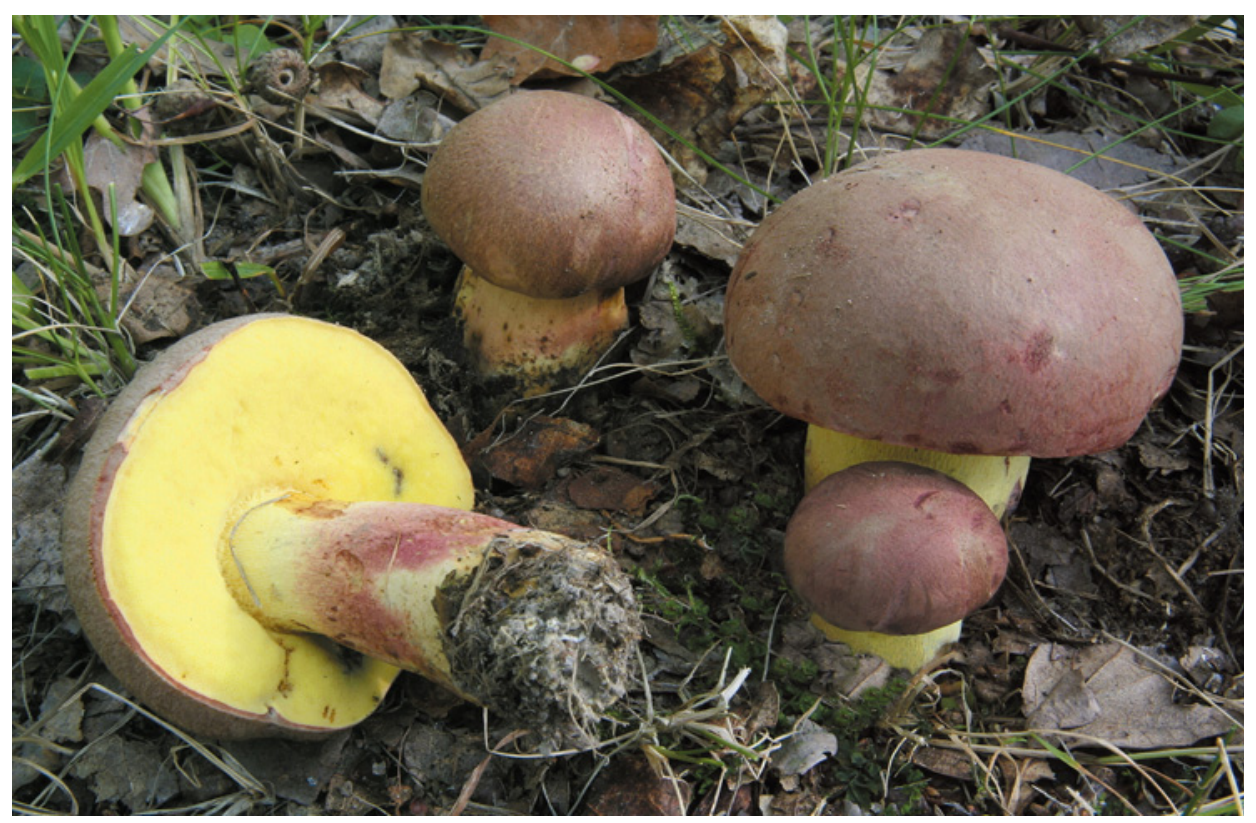

Fig. 17. Boletus fuscoroseus, Czech Republic, Běrunice, Kněžičky Game Preserve, under Quercus, 28 Sept. 2011 (JŠ 5917-5918). Photo J. Šutara. 


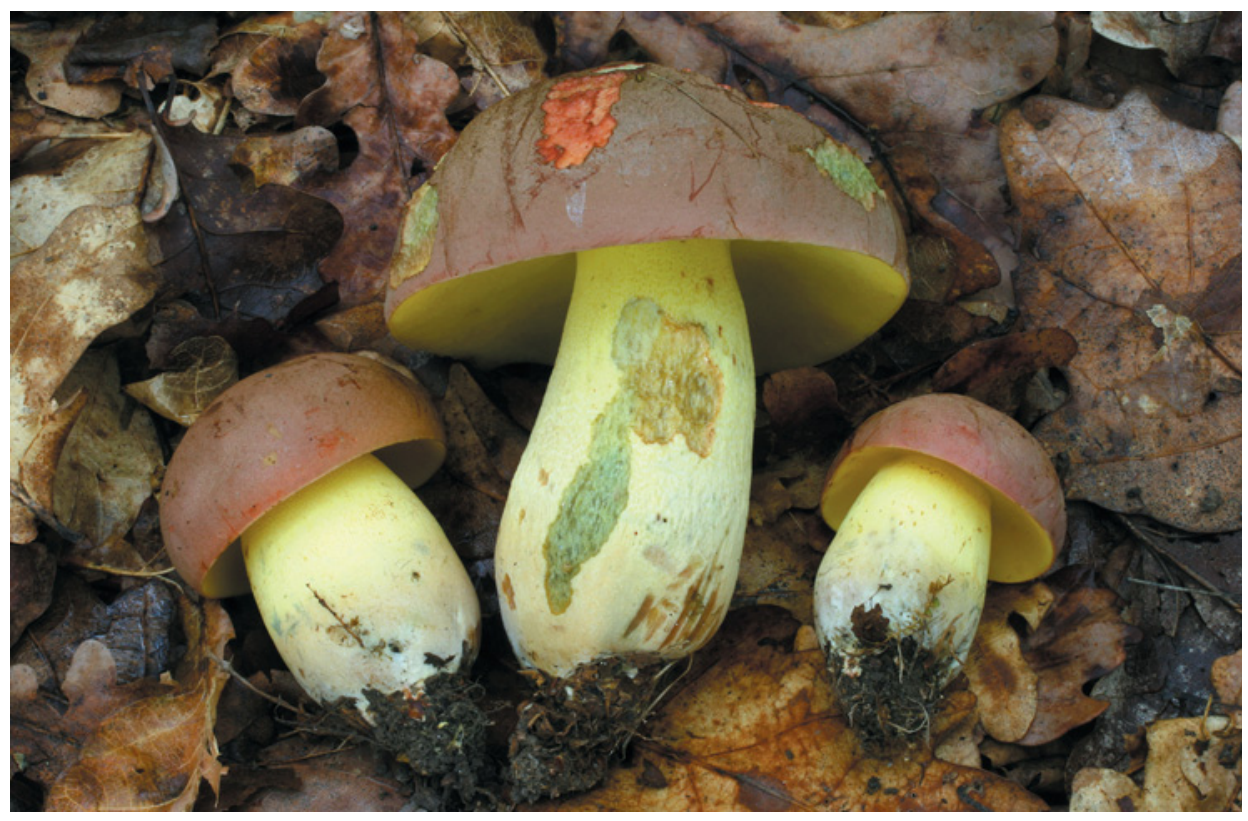

Fig. 18. Boletus fuscoroseus, Czech Republic, Běrunice, Kněžičky Game Preserve, under Quercus, 28 June 2009 (PRM 923676). Photo V. Janda.

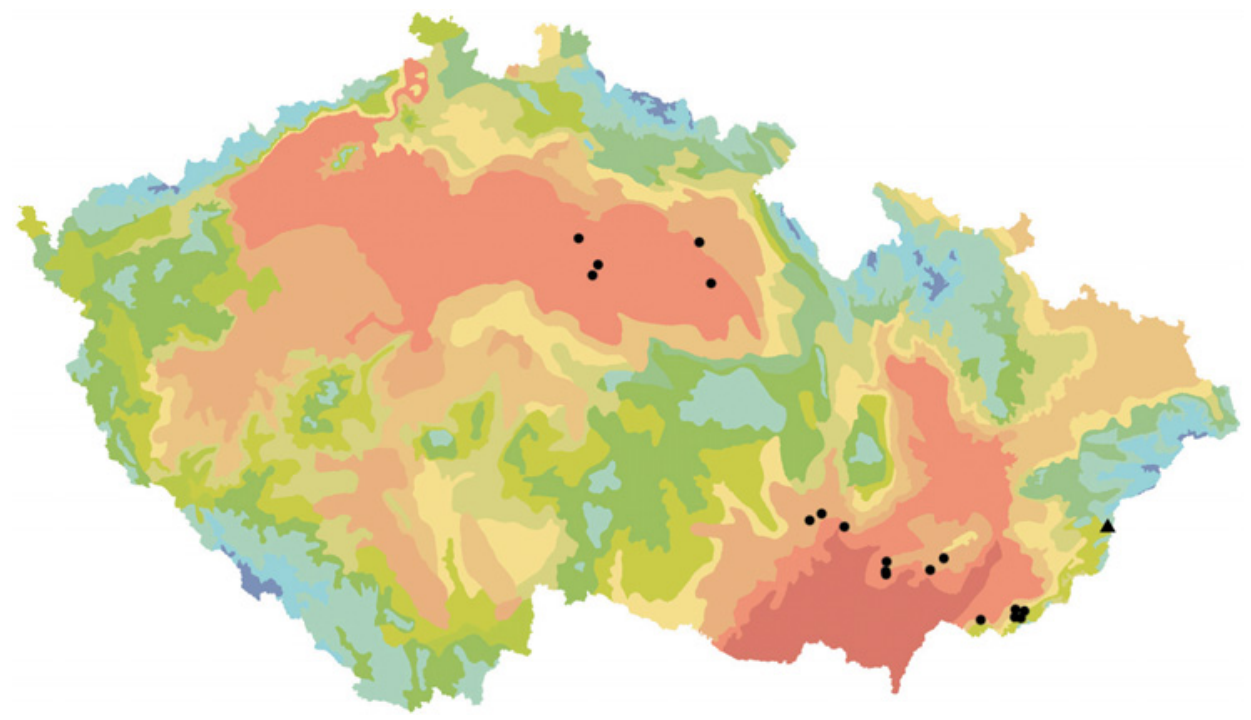

Fig. 19. Distribution of Boletus fuscoroseus $(\bullet)$ and Boletus roseogriseus ( $\mathbf{\wedge})$ in the Czech Republic (compiled using http://mapy.nature.cz, ( C) ČZK, Arcdata Praha, s.r.o., T-MAPY spol. s r.o., @ Demek \& Mackovčin 2006). 
dominating brownish shades, later at times discolouring to light ochreous or pale brownish, but almost always with remnants of a slight pinkish tint at least in some places (mostly in marginal zone), slowly darkening where bruised. Places bitten by slugs yellow when fresh, then very slowly becoming reddish to reddish purple or red-brownish. Surface dry, mat, initially subtomentose, soon becoming appressed filamentose (often looking almost glabrous by the naked eye), but (when observed under magnifying glass) covered with darker, very fine fibrils or fibrillose squamulae on a lighter background. Subcuticular context layer red, redpurplish, purplish brown or brown.

Tub e s at first light yellow, decurrent, later bright yellow, finally with a more or less distinct yellow-olivaceous tinge, 10-20 mm long and somewhat depressed around the stipe when mature, blueing or blue-greening when cut. Pores concolorous with tube sides, at first closed, then small, roundish, not larger than $1 \mathrm{~mm}$ at maturity; quickly blueing or blue-greening when bruised.

Spore-print olivaceous brown when fresh.

Stipe 50-100(140) × 20-35(40) mm, initially ventricose-fusiform, then cylindrical or subclavate, at times slightly swollen in the middle part, obtuse or tapering at the base, sometimes with a small, often overlooked, up to $15 \mathrm{~mm}$ large appendix, pale yellowish, light yellow to bright yellow overall or at least in the upper part, often with a pinkish, orange-reddish, red to purplish red zone in the lower third or even in the lower two thirds, but in some fruit bodies this reddish zone is developed only partially or even not developed at all (see Fig. 18). Surface covered with a fine, yellow or pale yellowish reticulum in the upper half. Bruised places on stipe surface blueing or blue-greening. Places bitten by slugs sometimes slowly becoming red, purple-reddish or red-brownish. Stipe base covered with whitish, at times partly yellowish or pale ochreous tomentum.

C o n t e xt light yellow in pileus and upper half of stipe when young, becoming partly whitish with age, usually pinkish to light carmine-rose in stipe base. This pinkish or carmine-rose shade is particularly distinct in fresh and younger fruit bodies, but gradually disappears in older or insufficiently fresh ones. Context in pileus and stipe apex blueing when cut. The blueing (like the pink colour in the stipe base) is less intensive in old or drying fruit bodies and, in such cases, it is usually only present above the tubes. Taste mild, pleasant, smell inconspicuous.

Microscopic characters. Pileus cuticle (pileipellis) a trichoderm composed of filamentous, (2.5)3-8(11) $\mu \mathrm{m}$ broad hyphae. The trichoderm, initially more or less anticlinally arranged, very soon collapses and changes into an appressed fibrillose layer. Walls of trichodermal hyphae thin, with smooth, slightly asperulate or distinctly incrusted surface. The non-incrusted trichodermal elements usually have a light content, but the incrusted hyphae are dark-coloured, brown in Melzer's reagent. These incrusted hyphae form filamentous strands of the dark fibrils and fibrillose squamulae on the pileus (see Fig. 20a) mentioned 
Czech Mycology 66(1): 1-37, JunE 4, 2014 (ONLINE VERSION, ISSN 1805-1421)

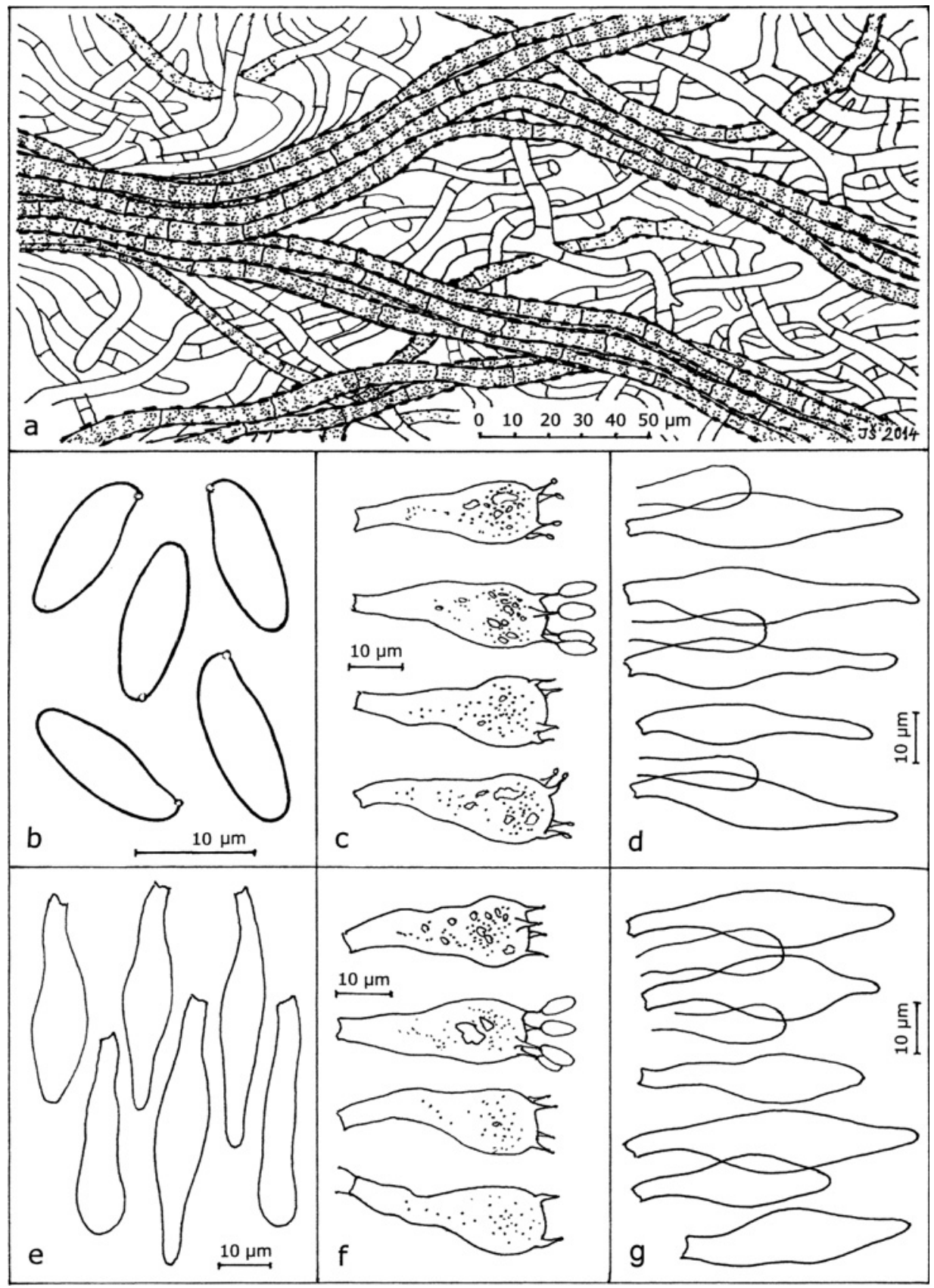

Fig. 20. Boletus fuscoroseus: a - scalp of pileipellis showing strands of incrusted hyphae (JŠ 5918); b spores (HR 86133 neotype, PRM 923474); c - basidia of hymenophore (VJ 290708-01); d - pleurocystidia (VJ 290708-01); e - cheilocystidia (JŠ 5844); f - caulobasidia (JŠ 5844); g - caulocystidia (JŠ 5844). Del. J. Šutara. 
already in the macroscopic description. The conspicuously incrusted hyphae usually occur in the pileipellis from early stages up to old age.

Hym en ophore. Hymenophoral trama bilateral, true boletoid, formed by a densely arranged mediostratum and loosely arranged, divergent lateral strata. Basidia (Fig. 20c) mostly 4-spored, clavate or clavate-capitate, 27-38(42) $\times 9-13$ $\mu \mathrm{m}$, with dispersed, dissolved and often partly granular or multiglobular content. Pleurocystidia (Fig. 20d) scattered, smooth and thin-walled, predominantly fusiform, 30-63 × 7-12.5 $\mu \mathrm{m}$. Cheilocystidia (Fig. 20e) very numerous, subcylindrical, subclavate or fusiform, (24)30-56 × (4.5)7-11 $\mathrm{mm}$, smooth and thin-walled, with pale yellowish, dispersed or dissolved content in Melzer's reagent.

Spores (Fig. 20b) of boletoid shape, fusoid-ellipsoid, with a suprahilar depression in side view, smooth under a light microscope, (10.0)11.0-13.5(15.8) $\times$ (4.1)4.4-5.1(5.9) $\mu \mathrm{m}, \mathrm{Q}=(2.20) 2.48-2.73(3.29), \mathrm{Q}_{\mathrm{av}}=2.61$, yellow to pale brownish in Melzer's reagent.

Stipe. Above-ground part of stipe covered with a fertile caulohymenium. Caulobasidia (Fig. 20f) 27-38 × 9-14 $\mu \mathrm{m}$, mostly 4-spored, rather abundant in the upper part of the stipe, clavate or clavate-capitate, with dissolved or dispersed and often partly granular or multiglobular content. Caulocystidia (Fig. 20g) of various shapes, fusiform, fusiform-rostrate, fusiform-ventricose or almost balloonshaped, abundant on ridges of stipe reticulation, 32-62 × 10-18 $\mu \mathrm{m}$, smooth and thin-walled, with a dispersed or dissolved content. Lateral stipe stratum distinctly developed particularly in upper part of stipe, loosely and divergently arranged, 30-40 $\mathrm{mm}$ thick in places between the reticulation ridges.

Context of pileus composed of filamentous and somewhat broadened hyphae, 3.5-16(20) pm wide, loosely and irregularly intertwined, smooth and thinwalled, with a yellowish, dissolved, dispersed or partly globular content (with globules up to $4 \mu \mathrm{m}$ ) in Melzer's reagent. Context of stipe consisting of filamentous and somewhat broadened hyphae densely and almost regularly arranged, more or less parallel with the longitudinal stipe axis, 4-25 $\mu \mathrm{m}$ wide, with content yellowish, dissolved or dispersed in Melzer's reagent. Hyphae with 'oily' content present in pileus context, pileipellis, hymenophoral trama, stipe context, and stipe surface layers. Reaction with Melzer's reagent: non-amyloid in all parts of fruit body. Clamp connections not found in the fruit body.

\section{Ecology and distribution}

Ecology. In deciduous, mainly oak and oak-hornbeam forests in thermophytic areas, rarely on dams and banks of ponds. Forming ectomycorrhizal association with Quercus, most frequently with Quercus robur. Symbiosis with Fagus, which is often mentioned in the literature (e.g. Pilát \& Dermek 1974, Breitenbach \& Kränzlin 1991, Gminder 2000, Muñoz 2005), has not been registered by us in the 
Czech Republic so far. The fruit bodies grow solitarily or in small groups from June to early October (exceptionally already at the end of May) with a maximum occurrence in July and August. The geological bedrock consists of calcareous claystone, marlite and possibly also calcareous siltstone in Bohemia, of claystone, sandstone and possibly also conglomerate in the West Carpathian flysch belt in Moravia, and of limestone and breccia, granodiorite or metabasalts and greenschist in the remaining cases. A joint element of all localities is alkaline soil. The altitudinal range is from 200 to $250 \mathrm{~m}$ a.s.l. in Bohemia, but up to ca. $400 \mathrm{~m}$ a.s.l. in Moravia. The only exception is the Bílé Karpaty Mts. (White Carpathians) in SE Moravia, where the bolete sometimes even exceeds an altitude of $500 \mathrm{~m}$ a.s.l. and often grows out of woods, under solitary oaks dispersed in the meadows.

Distribution. Boletus fuscoroseus is very rare in the Czech Republic. Its distribution correlates with the presence of other thermophilous boletes. Although we have some partial data related to occurrence of this species in Bohemia and Moravia, the general distribution in the Czech Republic is still not clearly known. The only large area of occurrence in Bohemia is a more or less flat landscape in the thermophytic region of Central and East Bohemia roughly between the towns of Nymburk, Kolín, Holice, and Hradec Králové. Next, the species occurs in the southern part of Moravia, namely in the environs of the town of Brno and in the hilly regions of Ždánický les uplands (long known site, see Vacek 1954), Chřiby hills and Bílé Karpaty Mts. For a general overview in the Czech Republic, based on recent finds, see Fig. 19.

Furthermore, we know this bolete from Štiavnické vrchy Mts. in Slovakia. For more details on the distribution in this country, see Pilát \& Dermek (1974, but only the locality of fruit bodies depicted in this work is relevant), and further Dermek \& Lizoň (1980, p. 516) and Hagara (1989, 1993). In the literature, there is a number of other data about records of $B$. fuscoroseus in the Czech Republic, but since the identification of fruit bodies is often questionable and sometimes just erroneous, we have not included these data in the distribution map in Fig. 19.

Boletus fuscoroseus is reported from many other European countries (often under the names B. pseudoregius or B. speciosus), but in most of them it is also rare, often only known from a few localities and listed as an endangered species in the national Red lists of macromycetes, including the Red list of fungi (macromycetes) of the Czech Republic (Graca 2006). Its main territory is the southern part of Europe, especially the Mediterranean area, where it is recorded more frequently, e.g. in Italy (Galli 1998, 2007, 2013, Boccardo et al. 2008), France (Marchand 1974, Courtecuisse \& Duhem 2000, Lannoy 2012), and Spain (Muñoz 2005, Marques \& Muñoz 2006, Domínguez 2007). 


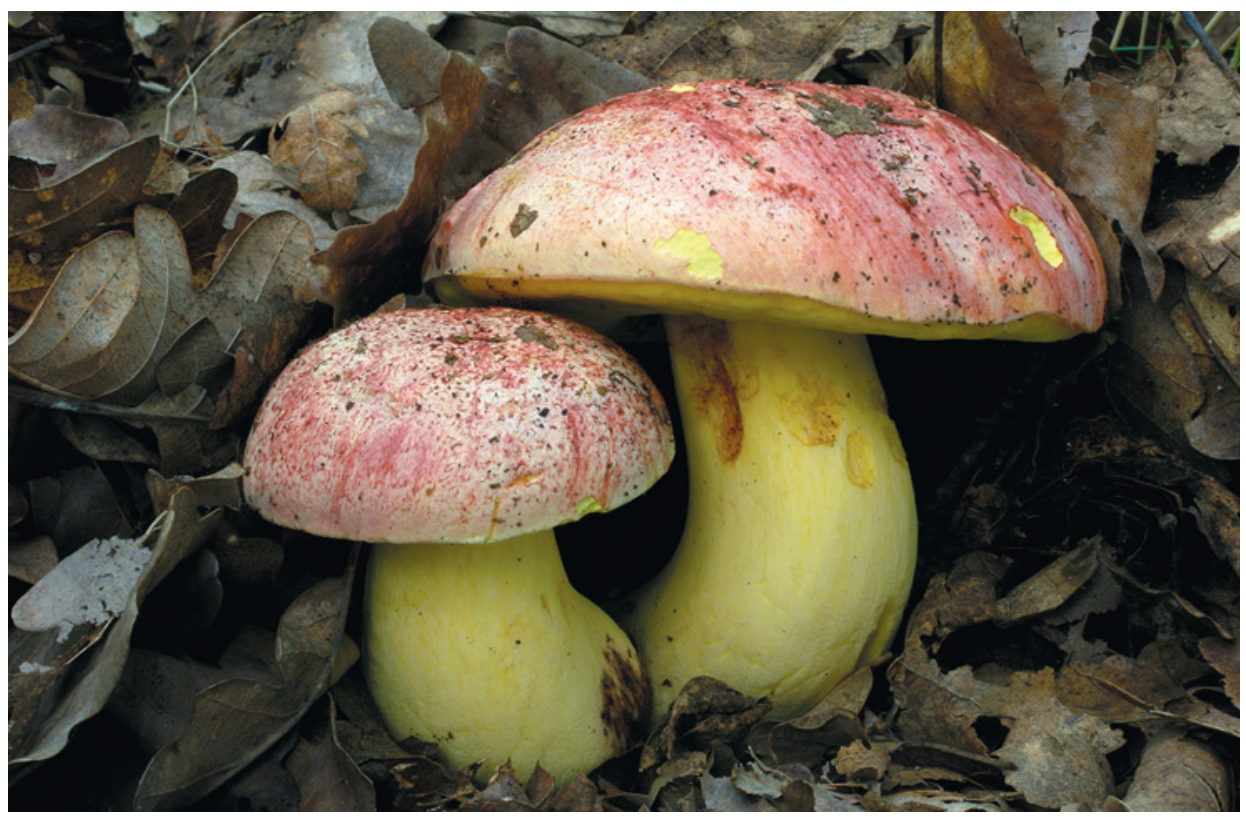

Fig. 21. Boletus regius, Czech Republic, Liteň, Mramor hill, under Quercus and Carpinus, 23 Sept. 2012 (PRM 923465, VJ 230912-02). Photo V. Janda.

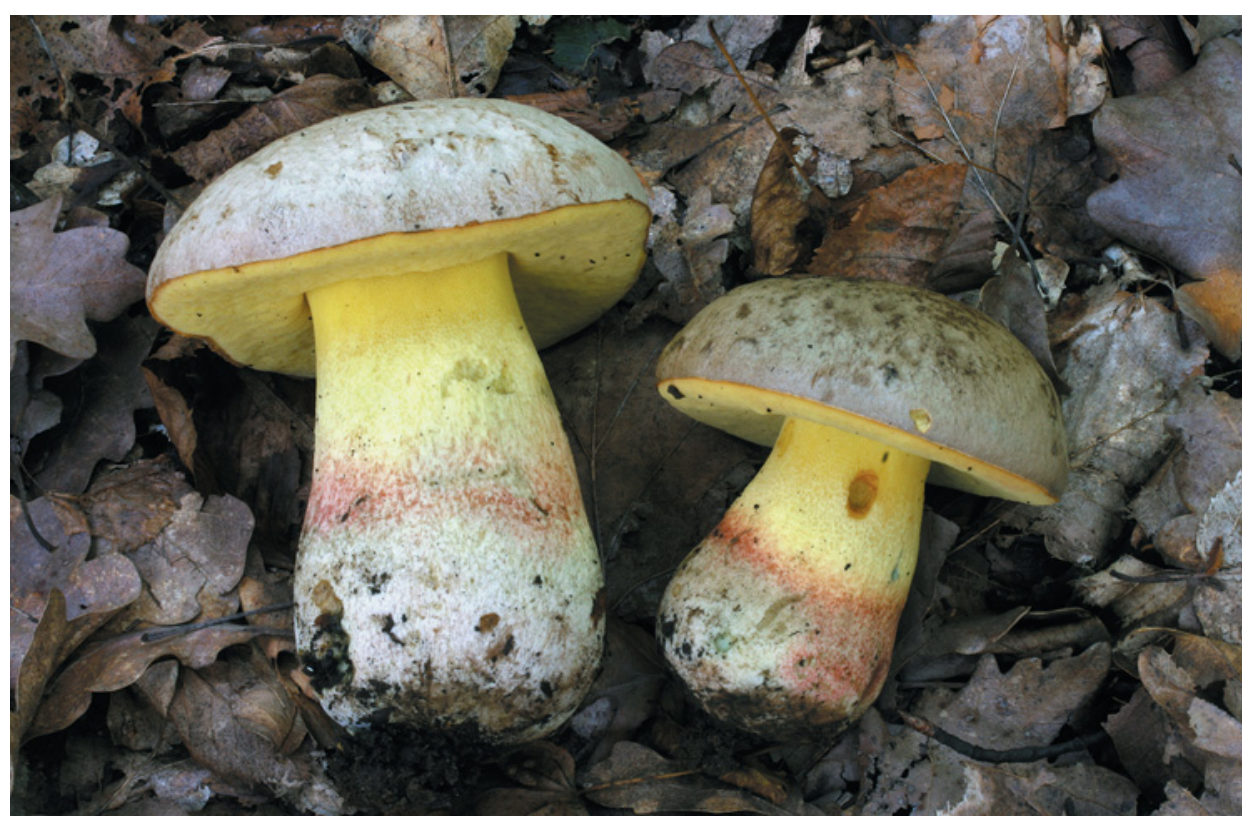

Fig. 22. Boletus fechtneri, Czech Republic, Srbsko, Karlštejn National Nature Reserve, Boubová hill, under Quercus, Tilia, Fagus and Carpinus, 8 Aug. 2010 (PRM 923468, VJ 080810-02). Photo V. Janda. 
Czech Mycology 66(1): 1-37, JunE 4, 2014 (ONLINE VERSION, ISSN 1805-1421)

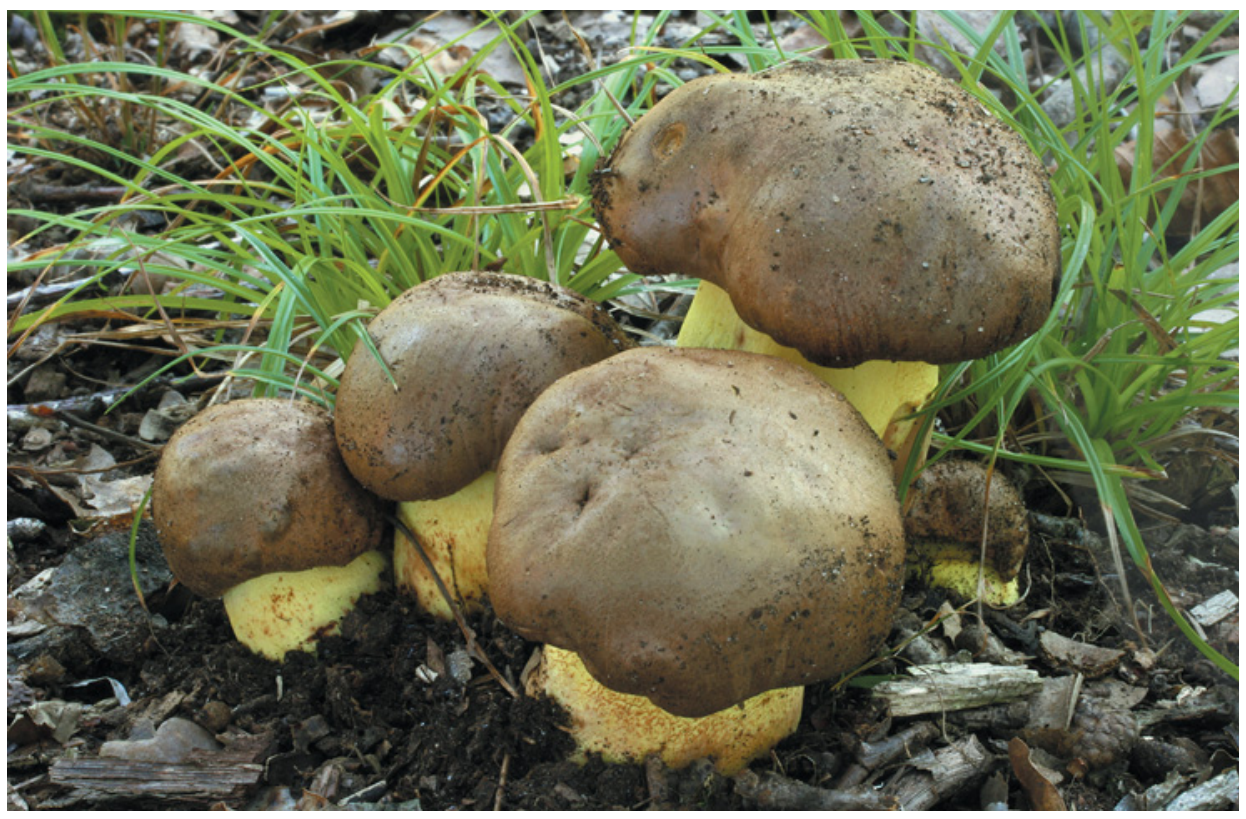

Fig. 23. Boletus appendiculatus, Czech Republic, Kněžičky, Kněžičky Game Preserve, under Quercus, 15 Aug. 2009 (PRM 923472, VJ 150809-01). Photo V. Janda.

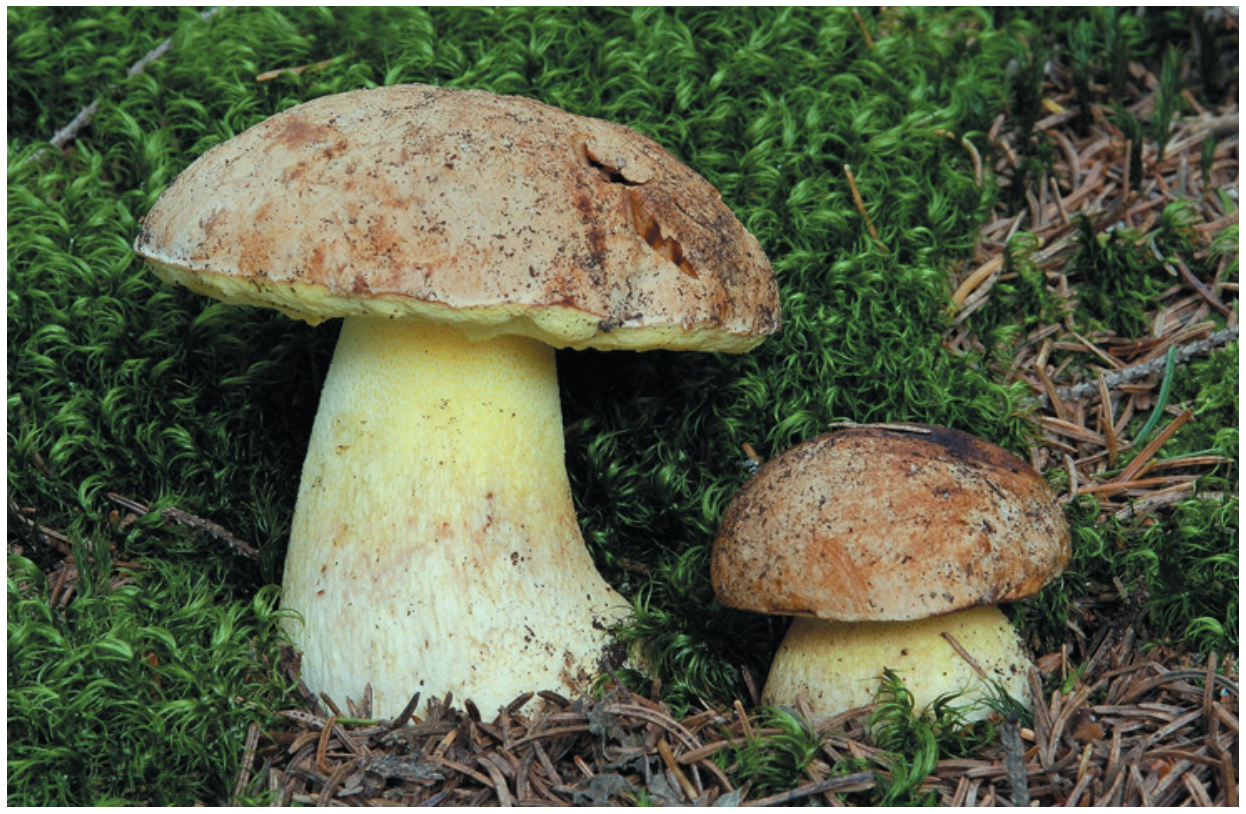

Fig. 24. Boletus subappendiculatus, Czech Republic, Bílá, Smradlava valley, under Picea, 26 Sept. 2007 (PRM 923478). Photo M. Graca. 


\section{Distinguishing characters}

Characters distinguishing Boletus fuscoroseus from the other European species of sect. Appendiculati are the following:

(1) Pileus with various brown pink, reddish brown or purplish brown coloration, sometimes discolouring to ochreous or pale brownish, but with remnants of a slight pinkish shade at least in some places, most frequently in marginal zone.

(2) Stipe yellow but often with a pinkish or reddish zone.

(3) Context in stipe base pinkish or light carmine-rose when young.

(4) Relatively deep blue oxidation of pileus context and tubes particularly when young.

(5) The most conspicuous incrustation of pileipellis hyphae in European species of sect. Appendiculati (see Fig. 20a).

(6) Growth under deciduous trees (most frequently Quercus) in thermophytic regions.

The characters distinguishing $B$. roseogriseus from $B$. fuscoroseus were already discussed (see Diagnosis and Distinguishing characters of $B$. roseogriseus).

B. subappendiculatus (Fig. 24) has the following characters different from B. fuscoroseus: coloration of pileus light ochreous or pale brownish without pink, reddish or purplish tints; yellow stipe without a pink or reddish coloured zone; not blueing or only slightly blueing context and tubes; growth under conifers in submontainous regions.

B. fechtneri (Fig. 22) differs from B. fuscoroseus mainly by its whitish, whitish grey, greyish, silvery grey, grey-brown or brownish, sometimes shiny pileus (without pinkish or reddish tints on its surface); distinctly broader spores, and less conspicuous incrustation of hyphae in the pileus cuticle.

B. regius (Fig. 21) differs from $B$. fuscoroseus above all by its pink, reddish pink or red pileus without any brownish shades; its unchanging or almost unchanging context and tubes; and its yellow stipe without a pink or reddish coloured zone.

B. appendiculatus (Fig. 23) differs from B. fuscoroseus by its brown pileus coloration without pink, red or red-purplish shades; a yellow stipe sometimes having brownish, but never reddish tints; the colour of its context in stipe base, which can sometimes be brownish, but is never pink or carmine-rose.

\section{History and nomenclature}

Boletus fuscoroseus was validly published by Smotlacha (1912). In his publication, Smotlacha well described most characters important for the definition of this species. In a shortened English translation of Smotlacha's description by Šutara (with explanatory notes in parentheses) it reads as follows: "Pileus ... brown with pink tint ... Tubes ... yellow ... with mouths roundish, small, coloured 
like the tubes ... blue-greening when bruised ... Stipe ... reticulated ... blue-greening when injured ... Context ... yellow-white ... blue-greening when injured. B. fuscoroseus is related to both preceding species (i.e. B. regius and B. aereus in Smotlacha's publication; however, it is necessary to explain that $B$. aereus in Smotlacha's sense is in fact B. appendiculatus - compare Smotlacha's description of B. aereus on pages $46-47$ of his publication). It (i.e. B. fuscoroseus) differs... from $B$. regius by blueing of context and tubes, from $B$. aereus (i.e. B. appendiculatus) by its pileus colour... Taste and character of the context are identical to those of both species (i.e. B. regius and B. appendiculatus) ... I first collected it (i.e. B. fuscoroseus) in Žernov forest near Holice under Quercus in August 1909 ...” (see Smotlacha 1912, p. 47-48).

One of the most important sentences in Smotlacha's description is his statement that B. fuscoroseus is related to both B. regius and B. appendiculatus. From this sentence, it is obvious that Smotlacha understood the taxonomic position of $B$. fuscoroseus correctly. The position of B. fuscoroseus between B. regius and $B$. appendiculatus is even supported by recent molecular studies of both ITS and LSU rDNA sequences.

Konrad (1925) considered the species which we name B. fuscoroseus only an infraspecific taxon and proposed a new combination, B. appendiculatus subsp. regius, for it. The same combination, with the name regius at the subspecies level, was also used by Konrad in Icones Selectae Fungorum (Konrad \& Maublanc 1924-37). Nomenclaturally, this name is a misinterpretation of Boletus regius Krombholz.

Huber (1938) published the same taxon as B. appendiculatus subsp. pseudoregius. Huber's publication of this subspecies name, however, is invalid because it was published without both a Latin description and designation of a type.

The epithet 'pseudoregius' was validly published only by Estadès (1988) who proposed the species name Boletus pseudoregius. When Estadès proposed this name, he mentioned the prior name $B$. fuscoroseus, but refused it without any convincing argument.

Another name used for the species discussed here, is B. speciosus sensu Singer (1967). This interpretation, however, seems to be untenable because the North American B. speciosus described by Frost (1874) is different from the European $B$. fuscoroseus in many respects. This is obvious from molecular data (see Figs. 1, 2), macroscopic appearance (see e.g. Snell \& Dick 1970, Bessette et al. 2000) as well as microscopic characters. We have examined a North American collection of B. speciosus (see Material examined, PRM 704843, 704844) and this material lacks a conspicuous incrustation of the pileipellis hyphae and its spores are only 3-4(4.5) $\mu \mathrm{m}$ broad, distinctly narrower than those of B. fuscoroseus.

Wichanský (1963) published information about collection of a bolete, for which he used the name B. fuscoroseus. Unfortunately, his description of this col- 
lection is somewhat confusing because some characters resemble $B$. fuscoroseus (e.g. blue-greening tubes), but some others [e.g. very narrow spores (3.5-4 $\mu \mathrm{m})$ and growth in submontainous region] rather correspond to a species, which was later described as $B$. subappendiculatus. It is necessary to add that the very narrow spores disagree with both $B$. roseogriseus and B. fuscoroseus as discussed in this paper.

Boletus wichanskyi Hlaváček (1993) was proposed as a nomen novum based on the above mentioned, slightly unclear description of Wichanský. This name is in fact a nomen invalidum proposed without a type designation.

Based on our study, we have come to the conclusion that B. fuscoroseus is a well-defined species. Unfortunately, despite of the fact that the name B. fuscoroseus has priority, it is often neglected in mycological literature. In order to avoid further confusion concerning the question of the correct name, we have designated a neotype for this species in this paper.

\section{Material examined}

Abbreviation s: alt. = altitude; leg. = collected by; det. = identified by; PRM = Mycological Department, National Museum, Prague; BRNM = Moravian Museum, Brno; CB = Museum of South Bohemia, České Budějovice; HR = Regional Museum of Eastern Bohemia, Hradec Králové; JŠ = personal herbarium of Josef Šutara; VJ = personal herbarium of Václav Janda; JK = personal herbarium of J. Kramoliš. Abbreviations of public herbaria follow Thiers (on-line). Names of the authors are shortened as follows: J.Š. (Josef Šutara), V.J. (Václav Janda), M.K. (Martin Kř́̌ž), and M.G. (Michal Graca).

\section{Boletus appendiculatus}

Czech Republic. Bohemia. Praha-Velká Chuchle (Central Bohemia, Pražská plošina plateau), Chuchelský háj, under Quercus, 1 Sept. 2007, leg. \& det. V.J. \& J.Š. (JŠ 5261). - Srbsko, Beroun District (Central Bohemia, Hořovická pahorkatina hills), Bohemian Karst, Karlštejn National Nature Reserve, eastern slope of Doutnáč hill, under Tilia, Picea, Quercus and Fagus, 26 July 2012, leg. \& det. M.K. (PRM 860513). - Břístev (Central Bohemia, Středolabská tabule plateau), northern bank of Komárovský pond, alt. 205 m, under Quercus, 19 Aug. 2007, leg. \& det. V.J., J. Rejsek \& J.Š. (JŠ 5099-5102); ibid., under Quercus and Carpinus, 1 Aug. 2010, leg. \& det. V.J., J. Rejsek \& T. Pavelka (PRM 923471, VJ 010810-01); ibid., under Quercus, 4 Aug. 2010, leg. \& det. J.Š. (JŠ 5524-5525). Dymokury (Central Bohemia, Středolabská tabule plateau), on bank of Pustý pond, under Quercus, 19 July 2007, leg. \& det. A. Vít \& J.Š. (JŠ 5095). - Záhornice, Nymburk District (Central Bohemia, Středolabská tabule plateau), northern bank of Jakubský pond, alt. 205 m, under Quercus, 19 July 2007, leg. \& det. V.J. \& J.ŠS. (JŠ 5106); ibid., under Quercus, 26 July 2007, leg. M. Vacková, det. J.Š. (JŠ 5130); ibid., under Quercus and Corylus, 28 July 2013, leg. \& det. M.K. \& P. Mikuš (PRM 922662); ibid., under Quercus, 24 Aug. 2013, leg. \& det. V.J. (PRM 923473, VJ 240813-04). - Kněžičky, Nymburk District (Central Bohemia, Středolabská tabule plateau), Kněžičky Game Preserve, alt. 250 m, under Quercus, 15 Aug. 2009, leg. \& det. V.J. \& J. Rejsek (PRM 923472, VJ 150809-01); ibid., under Quercus, 11 Aug. 2011, leg. \& det. J. Rejsek \& J.Š. (JŠ 5877-5878); ibid., under Quercus, 28 Sept. 2011, leg. \& det. V.J., J. Rejsek \& J.Š. (JŠ 5904-5912). - Turovec (South Bohemia, Táborská pahorkatina hills), on dam of Luční pond, under Quercus, 7 Sept. 1991, leg. \& det. P. Špinar \& J.Š. (JŠ 5095); ibid., under Quercus, 19 Sept. 2012, leg. \& det. P. Špinar \& J.Š. (JŠ 6163-6164).

Slovakia. Mochovce near Levice (Central Slovakia, Štiavnické vrchy Mts.), 5 Aug. 1975, leg. V. Holubová, det. F. Kotlaba (PRM 775391). 


\section{Boletus fechtneri}

Czech Republic. B o h emia. Srbsko, Beroun District (Central Bohemia, Hořovická pahorkatina hills), Bohemian Karst, Karlštejn National Nature Reserve, north-western slope of Boubová hill, alt. 340 m, under Quercus, Tilia, Fagus and Carpinus, 8 Aug. 2010, leg. \& det. V.J. (PRM 923468, VJ 080810-02). - Suchomasty (Central Bohemia, Hořovická pahorkatina hills), Bohemian Karst, Na Voskopě Nature Reserve, on edge of limestone quarry named Čertovy schody, alt. 460 m, under Quercus, 22 Aug. 2013, leg. V.J. \& L. Opat, det. V.J. (PRM 923470, VJ 220813-06). - Nouzov near Dymokury (Central Bohemia, Středolabská tabule plateau), southern bank of Komárovský pond, under Quercus, 10 July 2008, leg. \& det. V.J. (JŠ 5300); ibid., under Quercus, Carpinus and Tilia, 4 Sept. 2008, leg. Z. Kučera, det. J.Š. \& Z. Kučera (JŠ 5433); ibid., under Quercus and Carpinus, 4 Aug. 2010, leg. \& det. J.Š. (JŠ 5434-5436). Dymokury (Central Bohemia, Středolabská tabule plateau), on bank of Pustý pond, under Quercus, 25 Sept. 2013, leg. L. Opat \& J.Š., det. V.J. \& J.Š. (JŠ 6206-6207). - Kněžičky, Nymburk District (Central Bohemia, Středolabská tabule plateau), Kněžičky Game Preserve, Kněžičky National Nature Reserve, alt. 240 m, under Quercus, 19 June 2010, leg. J. Rejsek, det. V.J. (PRM 923469, VJ 190610-02); ibid., under Quercus, 20 Aug. 2011, leg. \& det. V.J. (JŠ 5837). - Chotovice (Central Bohemia, Východolabská tabule plateau), Bažantnice forest NE of the village of Dománovice, under Quercus, Carpinus and Betula, 28 July 2013, leg. M.K. \& P. Mikuš, det. M.K. (PRM 922665). - Choceň (East Bohemia, Orlická tabule plateau), Homole hill, under Tilia, Carpinus and Quercus, 5 July 2012, leg. \& det. M. Mička, P. Brůžek, M.K. \& O. Jindřich (PRM 860499).

Sweden. Upland: Ljusterö parish, Siarö, Kalvholmen, under Quercus, 29 Aug. 1951, leg. O. Persson (PRM 518242) (ex Fungi Exsiccati Suecici No. 2607 of S. Lundell \& J.A. Nannfeldt).

\section{Boletus fuscoroseus}

Czech Republic. B oh e mi a. Horní Ředice near Holice (East Bohemia, Východolabská tabule plateau), Žernov forest, on dam of Smilek pond, alt. 260 m, under Quercus robur, 6 Aug. 2010, leg. \& det. J. Kramoliš (neotype HR 86133, isoneotype PRM 923476). - Dymokury (Central Bohemia, Středolabská tabule plateau), on bank of Pustý pond, under Quercus and Carpinus, 25 Sept. 2011, leg. T. Pavelka, det. T. Pavelka \& V.J. (VJ 250911-01); ibid., under Quercus, Corylus, Acer campestre and Crataegus, 22 Aug. 2013, leg. M.K. \& P. Mikuš, det. M.K. (PRM 923621). - Běrunice (Central Bohemia, Středolabská tabule plateau), Kněžičky Game Preserve, alt. 240 m, under Quercus, 24 June 2008, leg. J. Rejsek, det. V.J. (PRM 923674, VJ 240608-01); ibid., under Quercus, 16 July 2008, leg. J. Rejsek, det. V.J. (CB 16305, VJ 160708-01-160708-02); ibid., under Quercus, 18 July 2008, leg. J. Rejsek, det. V.J. (PRM 923675, VJ 180708-01); ibid., under Quercus, 20 July 2008, leg. J. Rejsek, V.J. \& N. Melichová, det. V.J. (VJ 200708-04); ibid., under Quercus, 22 July 2008, leg. \& det. V.J. (VJ 220708-01); ibid., under Quercus, 25 July 2008, leg. \& det. V.J. (CB 16306); ibid., under Quercus, 29 July 2008, leg. \& det. V.J. (VJ 290708-01); ibid., under Quercus, 30 May 2009, leg. J. Rejsek, det. V.J. (PRM 923683, VJ 300509-05); ibid., under Quercus, 13 June 2009, leg. \& det. V.J. \& J. Rejsek (VJ 130609-08); ibid., under Quercus, 23 June 2009, leg. \& det. V.J. \& J. Rejsek (PRM 923475, VJ 230609-01); ibid., under Quercus, 28 June 2009, leg. \& det. V.J. (PRM 923676, VJ 280609-04); ibid., under Quercus, 18 July 2009, leg. \& det. V.J. \& J. Rejsek (PRM 923677, VJ 180709-01); ibid., under Quercus, 21 July 2009, leg. \& det. V.J. (PRM 923678, VJ 21070906); ibid., under Quercus, 23 July 2009, leg. \& det. V.J. \& J. Rejsek (PRM 923679, VJ 230709-03); ibid., under Quercus, 26 July 2009, leg. \& det. V.J. (VJ 260709-02); ibid., under Quercus, 31 July 2010, leg. \& det. V.J. \& J. Rejsek (PRM 923680, PRM 923681, VJ 310710-01-310710-02, VJ 310710-12); ibid., under Quercus, 22 Aug. 2010, leg. P. Janda, det. V.J. (PRM 923685, VJ 220810-02); ibid., under Quercus, 3 Sept. 2010, leg. \& det. J.Š. (JŠ 5701); ibid., under Quercus, 11 Aug. 2011, leg. J. Rejsek \& J.Š., det. J.Š. \& J. Rejsek (JŠ 5823); ibid., under Quercus, 20 Aug. 2011, leg. J.Š., J. Rejsek \& V.J., det. J.Š. \& V.J. (JŠ 5844-5846, VJ 200811-01); ibid., under Quercus, 24 Sept. 2011, leg. J. Rejsek, N. Melichová \& V.J., det. V.J. (PRM 923474, VJ 240911-04); ibid., under Quercus, 28 Sept. 2011, leg. J. Rejsek, V.J. \& J.Š., det. J.Š. \& V.J. (JŠ 5917-5918); ibid., under Quercus, 1 Oct. 2011, leg. \& det. V.J. \& J. Rejsek (PRM 923684, VJ 011011-06); ibid., under Quercus, 14 Aug. 2012, leg. \& det. J. Kramoliš \& T. Tejklová (HR 90443, JK 1054); ibid., under Quercus, 9 Sept. 2012, leg. V.J. \& L. Opat, det. V.J. (PRM 923682, VJ 090912-03); ibid., under 
Quercus, 15 Sept. 2012, leg. \& det. V.J. \& J. Rejsek (VJ 150912-04). - Žehuň (Central Bohemia, Východolabská tabule plateau), Kozí hůra hill, under Quercus and Carpinus, 15 Aug. 2009, leg. \& det. M. Mikšík (JŠ 6215). - Slatina near Hradec Králové (East Bohemia, Orlická tabule plateau), Ouliště forest, alt. 250 m, under Quercus, 12 July 2013, leg. \& det. F. Pavlík (HR 91831). - M o r a vi a. Kanice, Brnovenkov District (South Moravia, Drahanská vrchovina uplands), Moravian Karst, Hádecká planinka National Nature Reserve, under Quercus and Corylus, 11 July 2010, leg. S. Valda, M.K. \& Z. Egertová, det. M.K. (PRM 899634). - Dambořice (South Moravia, Ždánický les uplands), south-eastern slope of Písečná hill, alt. 305 m, under Quercus and Carpinus, 10 Aug. 2011, leg. \& det. M. Mička \& J. Kramoliš (HR 87890). - Velké Hostěrádky (South Moravia, Ždánický les uplands), Líchy hill, alt. 325 m, deciduous forest, 27 Aug. 2013, leg. \& det. S. Flekrová, T. Tejklová \& J. Kramoliš (HR 91840). - Bohuslavice near Kyjov (South Moravia, Chřiby hills), valley of Bohuslavický stream S of Lenivá hora hill, alt. 330 m, under Quercus and Carpinus, 31 July 2008, leg. \& det. J. Běták, rev. J.Š. (JŠ 6221). - Kněždub (South Moravia, Bílé Karpaty Mts.), SE of the village, former orchard, alt. ca. $260 \mathrm{~m}$, under Tilia and Quercus, 28 Aug. 2006, leg. V. Chudíček, det. P. Štastný \& V.J. (PRM 923673, VJ 280806-03); ibid., under Tilia and Quercus, 1 Sept. 2006, leg. V. Chudíček, det. V.J. (VJ 010906-02).

Slovakia. Ladzany (Central Slovakia, Štiavnické vrchy Mts.), Studenec valley, under Quercus, 9 Sept. 1998, leg. \& det. M.G. (JŠ 4244). - Ladzany (Central Slovakia, Štiavnické vrchy Mts.), forest plantations covering Háj and Velký Gregor hills, under Quercus, 12 Aug. 2010, leg. \& det. M.K. (JŠ 5644-5645).

\section{Boletus regius}

Czech Republic. Bohemia. Praha-Točná (Central Bohemia, Pražská plošina plateau), in vicinity of the villages of Točná and Závist, alt. 310 m, under Quercus, 10 Sept. 2010, leg. \& det. L. Opat \& V.J. (PRM 923466, VJ 100910-01); ibid., under Quercus, 16 July 2012, leg. \& det. L. Opat (JŠ 6204). Jíloviště (Central Bohemia, Brdská vrchovina uplands), Strnady, under Quercus and Carpinus, 15 Sept. 1985, leg. M. Kotábová, det. Z. Pouzar (PRM 866632). - Štěchovice, Praha-západ District (Central Bohemia, Benešovská pahorkatina hills), under Quercus, 26 Aug. 1961, leg. Kaislerová, det. M. Svrček (PRM 615709). - Karlík (Central Bohemia, Pražská plošina plateau), Bohemian Karst, Krásná stráň Nature Monument, alt. 300 m, under Quercus, 14 May 2009, leg. \& det. T. Wagner \& J.Š. (JŠ 6199); ibid., under Quercus, 21 May 2009, leg. \& det. T. Wagner (JŠ 6200). - Měňany (Central Bohemia, Hořovická pahorkatina hills), Bohemian Karst, between the villages of Měňany and Korno, under Quercus, 14 May 2009, leg. \& det. V.J. \& J.Š. (JŠ 6196-6197); ibid., under Quercus, 26 July 2011, leg. \& det. M.K. (JŠ 6222). - Liteň (Central Bohemia, Hořovická pahorkatina hills), Bohemian Karst, Mramor hill, alt. 410 m, under Quercus and Carpinus, 24 July 2012, leg. \& det. L. Opat (JŠ 6205); ibid., under Quercus and Carpinus, 23 Sept. 2012, leg. \& det. V.J., L. Opat \& T. Pavelka (PRM 923465, VJ 230912-02). - Komárov near Hořovice (Central Bohemia, Brdská vrchovina uplands), on dam of Červený pond, alt. 410 m, under Quercus, 17 July 1992, leg. \& det. O. Jindřich (JŠ 3525); ibid., under Quercus, 7 Sept. 1997, leg. \& det. O. Jindřich (JŠ 6213). - Nouzov near Dymokury (Central Bohemia, Středolabská tabule plateau), south bank of Komárovský pond, alt. 200 m, under Quercus and Tilia, 21 Aug. 2010, leg. \& det. J. Rejsek \& V.J. (PRM 923467, VJ 210810-02). - M o r a vi a. Jinačovice (South Moravia, Bobravská vrchovina uplands), Sychrov hill, under Quercus, 25 Aug. 2006, leg. \& det. L. Straka (JŠ 5227).

Croatia. Rabac (Istria), under Quercus, 8 Sept. 1976, leg. V. Vyčichlo, det. J. Šutara (JŠ 044).

\section{Boletus roseogriseus}

Czech Republic. Moravia. Javorníky Mts., ca. $1 \mathrm{~km}$ SE of the village of Francova Lhota, forest plantations covering north-western slopes of Tisůvek and Čubův kopec hills, alt. 580-595 m, under Abies, Picea and Corylus, 13 Aug. 2010, leg. M.G, det. J.Š., M.G., V.J., M.K. \& M. Kolařík (holotype PRM 923483); ibid., under Abies, Picea and Corylus, 26 Aug. 2010, leg. M.G. \& J.Š., det. J.Š., M.G., V.J., M.K. \& M. Kolařík (JŠ 6188); ibid., under Abies, Picea, Corylus and Sorbus, 1 Aug. 2012, leg. M.G. \& V. Balner, det. J.Š., M.G., V.J., M.K. \& M. Kolařík (PRM 923480); ibid., under Abies, Picea and Corylus, 17 Aug. 2012, leg. M.G., det. J.Š., M.G., V.J., M.K. \& M. Kolařík (PRM 923482); ibid., other microlocality, alt. 585 m, under Abies, Picea, Quercus, Pinus, Populus tremula and Larix, 18 Aug. 2010, leg. M.G. \& J. Polčák, det. J.Š., M.G., V.J., M.K. \& M. Kolařík (JŠ 6191); ibid., other microlocality, alt. 585 m, under Abies, Picea 
and Betula, 18 Aug. 2010, leg. M.G. \& J. Polčák, det. J.Š., M.G., V.J., M.K. \& M. Kolařík (JŠ 6192, 6193); ibid., other microlocality, alt. 610 m, under Picea and Abies, 8 Aug. 2012, leg. M.G. \& V. Balner, det. J.Š., M.G., V.J., M.K. \& M. Kolař́k (PRM 923481); ibid., other microlocality, alt. 600 m, under Abies and Picea, 20 July 2012, leg. M.G. \& V. Balner, det. J.Š., M.G., V.J., M.K. \& M. Kolařík (PRM 923479).

\section{Boletus speciosus}

USA. N.Y., Langford Erie County, 14 Sept. 1968, leg. \& det. E. Both (PRM 704843); ibid., 24 Sept. 1968, leg. \& det. E. Both (PRM 704844).

\section{Boletus subappendiculatus}

Czech Republic. Moravia. Bílá, Frýdek-Místek District (North Moravia, Moravskoslezské Beskydy Mts.), Smradlava valley, near forest path linking Malá Smradlava and Smradlava valleys, alt. 620-630 m, under Picea, 26 Sept. 2007, leg. \& det. M.G. \& V. Balner (PRM 923478); ibid., under Picea, 24 July 2013, leg. \& det. M.G. (PRM 923477).

Slovakia. Važec (North Slovakia, Podtatranská kotlina basin), alt. 850 m, under Picea, 4 Sept. 1980, leg. J.Š., det. J.Š. \& J. Kuthan (JŠ 318).

\section{ACKNOWLEDGEMENTS}

We are very grateful to Zdeněk Pouzar, National Museum, Prague for useful advice on preparing the manuscript of this paper. We thank Miroslav Beran of the Museum of South Bohemia, České Budějovice, for kind assistance with the translation of French literature sources, Tereza Tejklová of the Museum of Eastern Bohemia, Hradec Králové, for kindly lending herbarium specimens, and Vladimír Antonín of the Moravian Museum, Brno, for providing information about collections deposited in the BRNM herbarium. We are also very grateful for valuable information and excellent field cooperation to (in alphabetical order): Vít Balner, Jan Běták, Ota Chlup, Jan Willem Jongepier, Jan Kramoliš, Petr Mikuš, Vlasta Ondrová, Lubomír Opat, Tomáš Pavelka, Jiří Polčák, Jiří Rejsek, and Luboš Straka. This work was financially supported by the Ministry of Culture of the Czech Republic (DKRVO 2014/06, National Museum, 00023272).

\section{REFERENCES}

ALESSIO C.L. (1991): Supplemento a Boletus Dill. ex L. (sensu lato). - Fungi Europaei 2A, 124 p., 8 pl., Giovanna Biella, Saronno.

ASsYov B. (2012): Revision of Boletus section Appendiculati (Boletaceae) in Bulgaria with key to the Balkan species. - Turk. J. Bot. 36: 408-419.

BessetTe A.E., Roody W.C., BessetTe A.R. (2000): North American boletes. - 396 p., 80 pl., Syracuse University Press, New York.

BINDER M., BRESINSKY A. (2002): Retiboletus, a new genus for a species-complex in the Boletaceae producing retipolides. - Feddes Repertorium 113: 30-40.

BINDER M., HiBBETT D.S. (2006): Molecular systematics and biological diversification of Boletales. Mycologia 98(6): 971-981.

Boccardo F., Traverso M., Vizzini A., ZotTi M. (2008): Funghi d'Italia. - 623 p., Zanichelli, Bologna. 
BOKR P. (on-line): Geologické a geovědní mapy [Geological and geoscientific maps]. http://www.geologicke-mapy.cz. [accessed March 2014; in Czech]

BREITENBACH J., KRÄNZLIN F. (1991): Fungi of Switzerland, vol. 3 Boletes and agarics, $1^{\text {st }}$ part. - 361 p., Mykologia, Lucerne.

Courtecuisse R., Duhem B. (2000): Champignons de France et d'Europe. - 476 p., Delachaux et Niestlé, Paris.

DEMEK J., MACKOvČIN P., eds. (2006): Zeměpisný lexikon ČR. Hory a nížiny. - 580 p. AOPK ČR, Brno.

DENTINGER B.T., DiDUKH M.Y., MONCALVO J.M. (2011): Comparing COI and ITS as DNA barcode markers for mushrooms and allies (Agaricomycotina). - PLoS ONE 6(9), E25081.

DERMEK A., LizoŇ P. (1980): Malý atlas húb [Small fungus atlas]. - 548 p., Slovenské pedagogické nakladatelstvo, Bratislava. [in Slovak]

Domínguez A.C. (2007): Guía de los Boletos de España y Portugal. - 407 p., Náyade Editorial, Medina del Campo, Valladolid.

Engel H., KRiEglsteiner G.J., Dermek A., WATLING R. (1983): Dickröhrlinge. Die Gattung Boletus in Europa. - 157 p., Schneider-Druck, Weidhausen.

ESTADÈS A. (1988): Boletus pseudoregius (Huber) comb. nov. - Bull. trimest. Féd. Mycol. DauphinéSavoie 27 (no. 108): 7-8.

Frost C.C. (1874): Catalogue of Boleti of New England, with descriptions of new species. - Bull. Buffalo Soc. nat. Sci. 2: 101.

GALLI R. (1998): I Boleti. - 287 p., Edinatura, Milano.

GALLI R. (2007): I Boleti. - 296 p., Dalla Natura, Milano.

GALLI R. (2013): I Boleti. - 296 p., Micologica, Pomezia.

GMINDER A. (2000): Boletus pseudoregius Huber ex Estadès. - In: Krieglsteiner G.J., ed., Die Großpilze Baden-Württembergs. Band 2: Ständerpilze: Leisten-, Keulen-, Korallen- und Stoppelpilze, Bauchpilze, Röhrlings- und Täublingsartige, p. 240-241, Ulmer, Stuttgart.

GRACA M. (2006): Boletus pseudoregius Huber ex Estadès. - In: Holec J., Beran M., eds., Červený seznam hub (makromycetů) České republiky [Red List of fungi (macromycetes) of the Czech Republic]. - Př́roda 24: 80. [in Czech]

GUINDON S., DUfAYARD J.F., LEFORT V., ANiSiMOVA M., HORDIJK W., GASCUEL O. (2010): New algorithms and methods to estimate maximum-likelihood phylogenies: assessing the performance of PhyML 3.0. - Systematic Biology 59(3): 307-321.

HAGARA L. (1989): Vzácne prvky slovenskej mykoflóry [Rare elements of the Slovak mycoflora]. Česká Mykol. 43(1): 51-60. [in Slovak]

HAGARA L. (1993): Atlas hub [Atlas of fungi]. - 461 p., Neografie, Praha. [in Czech]

HAGARA L., ANTONín V., BAIER J. (1999): Houby [Fungi]. - 416 p., Aventinum, Praha. [in Czech]

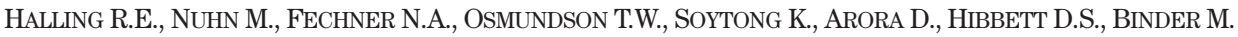
(2012): Sutorius: a new genus for Boletus eximius. - Mycologia 104 (4): 951-961.

HLAVÁČEK J. (1993): Přehled našich hub hřibotvarých - Boletales (21) [Survey of our Boletales]. Mykologický sborník 70(1-2): 2-12. [in Czech]

HOLEC J., KOLAŘ́́K M. (2013): Ossicaulis lachnopus (Agaricales, Lyophyllaceae), a species similar to O. lignatilis, is verified by morphological and molecular methods. - Mycological Progress 12: 589-597.

HUBER H. (1938): Der Königs-Röhrling. Boletus regius. - Z. f. Pilzk. 17(3-4): 86-87.

KATOH K., TOH H. (2008): Improved accuracy of multiple ncRNA alignment by incorporating structural information into a MAFFT-based framework. - BMC Bioinformatics 9(1): 212.

KIBBY G. (2012): British Boletes with keys to species. $4^{\text {th }}$ ed. -79 p., London.

KLOFAC W. (2007): Schlüssel zur Bestimmung von Frischfunden der europäische Arten der Boletales mit röhrigem Hymenophor. - Öster. Z. Pilzk. 16: 187-279.

KNUDSEn H., TAYLOR A. (2012): Boletus L.: Fr. - In: Knudsen H., Vesterholt J., eds., Funga Nordica. Agaricoid, boletoid, clavarioid, cyphelloid and gastroid genera, p. 217-222, Nordsvamp, Copenhagen. 
KONRAD P. (1925): Notes critiques sur quelques champignons du Jura II. - Bull. Soc. mycol. Fr. 41(1): $33-70$.

KonRad P., MAUBlanC A. (1924-37): Icones Selectae Fungorum, Vol. I-VI. - 500 pl., Lechevalier, Paris.

LANNOY G. (2012): Iconographie des Bolets d'Europe. - 35 p., 82 pl., Société mycologique du Nord de la France, Lille.

LANNOY G., EsTADÈs A. (2001): Les Bolets. - In: Bon M., ed., Flore Mycologique d'Europe 6, p. 1-161, $6 \mathrm{pl}$. Association d'Écologie et de Mycologie, Lille.

LANNOY G., ESTADÈS A. (2004): Les bolets européens. - Bull. mycol. bot. Dauphiné-Savoie, 44 (no. 174): $3-79$.

Li H., Wei H., Peng H., DiNG H., WANG L., HE L., FU L. (2014): Boletus roseoflavus, a new species of Boletus in section Appendiculati from China. - Mycol. Progress 13(1): 21-31.

Marchand A. (1974): Champignons du Nord et du Midi. Boletales et Aphyllophorales. - 275 p., Société mycologique des Pyrénées méditerranéennes, Perpignan.

MARQUES G., MUÑOZ J.A. (2006): Révision des espèces européennes du genre Boletus section Appendiculati. Étude sur la base des caractères morphologiques et d'analyse des polymorphismes des fragments de restriction (PCR-RFLP). - Bull. Soc. mycol. Fr. 122(4): 353-366.

MARTíN M.P., MORENO G. (2001): Molecular data confirm Setchelliogaster tenuipes and S. rheophyllus as Cortinariales. - Mycotaxon 78: 257-263.

MoRRIS M.H., PEREZ-PEREZ M.A., SMITH M.E., BLEDSOE C.S. (2008): Multiple species of ectomycorrhizal fungi are frequently detected on individual oak root tips in a tropical cloud forest. - Mycorrhiza 18(8): 375-383.

MuÑoz J. A. (2005): Boletus s. l. (excl. Xerocomus). - Fungi Europaei 2, 951 p., 428 pl., Edizioni Candusso, Alassio.

Nuhn M.E., Binder M., TAYLOR A.F., Halding R.E., HibBeTt D.S. (2013). Phylogenetic overview of the Boletineae. - Fungal Biology 117: 479-511.

O’DonNELL K. (1993): Fusarium and its near relatives. - In: Reynolds D.R. \& Taylor J.W., eds., The fungal holomorph: mitotic, meiotic and pleomorphic speciation in fungal systematics, p. 225-233, CAB International, Wallingford.

OSMUNDSON T.W., ROBERT V.A., Schoch C.L., BAKER L.J., SMith A., ROBich G., MizzAn L., GARBElotTo M.M. (2013): Filling gaps in biodiversity knowledge for macrofungi: contributions and assessment of an herbarium collection DNA barcode sequencing project. - PLoS ONE 8(4), E62419.

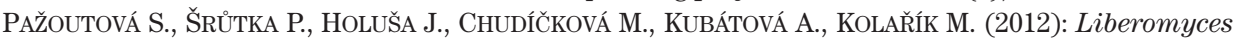
gen. nov. with two new species of endophytic coelomycetes from broadleaf trees. - Mycologia 104(1): 198-210.

Pilát A., DeRmeK A. (1974): Hríbovité huby [Boletoid fungi]. - 207 p., 103 pl., Veda, Bratislava. [in Slovak].

REDEUILH G., Simonini G. (2002): Comité pour l'unification des noms de Bolets Européens. - Bull. Soc. mycol. Fr. 118(2): 139-153.

SCHREINER J. (1998): Zum Vorkommen der Röhrlinge (Boletaceae) in Unterfranken und angrenzenden Gebieten. - Mitt. naturwiss. Mus. Aschaffenburg 17: 3-162.

SINGER R. (1967): Die Röhrlinge II. Die Boletoideae und Strobilomycetaceae. - Die Pilze Mitteleuropas, Band VI, 151 p., 26 pl., Justus Klinkhardt, Bad Heilbrunn.

SMOTLACHA F. (1912): Monografie českých hub hřibovitých (Boletineí) [Monograph of Czech boletoid fungi]. - Věstn. Král. čes. spol. nauk 1911, tř. mat. př́r., no. 8: 1-73. [in Czech]

SNELL W.H., DiCK E.A. (1970): The Boleti of Northeastern North America. - 115 p., 87 pl., J. Cramer, Lehre.

ŠUTARA J. (2005): Central European genera of the Boletaceae and Suillaceae, with notes on their anatomical characters. - Czech Mycol. 57: 1-50.

ŠUTARA J., MIKŠ́́K M., JANDA V. (2009): Hřibovité houby. Čeled' Boletaceae a rody Gyrodon, Gyroporus, Boletinus a Suillus [Boletoid fungi. Family Boletaceae and genera Gyrodon, Gyroporus, Boletinus, and Suillus]. - 294 p., Academia, Praha. [in Czech] 
TAmura K., Peterson D., Peterson N., Stecher G., Nei M., Kumar S. (2011): MEGA5: molecular evolutionary genetics analysis using maximum likelihood, evolutionary distance, and maximum parsimony methods. - Molecular Biology and Evolution 28(10): 2731-2739.

THIERs B. (on-line) [continuously updated]: Index Herbariorum: A global directory of public herbaria and associated staff. New York Botanical Garden's Virtual Herbarium. http://sweetgum.nybg.org/ih/. [accessed March 2014]

THIERs H.D. (1975): California Mushrooms - A field guide to the Boletes. - 261 p., Hafner Press, New York.

Toju H., TANabe A.S., Yamamoto S., SATo H. (2012): High-coverage ITS primers for the DNA-based identification of Ascomycetes and Basidiomycetes in environmental samples. - PLoS ONE 7(7): e40863.

VACEK V. (1954): Hřib hnědorůžový čili růžovník - Boletus fuscoroseus Sm. - Česká Mykol. 8: 45-46. [in Czech]

VELENOvSKÝ J. (1922): České houby II [Czech fungi II]. - p. 633-950, Česká botanická společnost, Praha. [in Czech]

WATLING R., HiLls A.E. (2005): Boletes and their allies. Revised and enlarged edition. - 172 p., Royal Botanic Garden, Edinburgh.

WiCHANSKÝ E. (1963): Růžovník - Boletus fuscoroseus Smotlacha 1910. - Mykologický sborník 40(5-6): 65-67. [in Czech] 